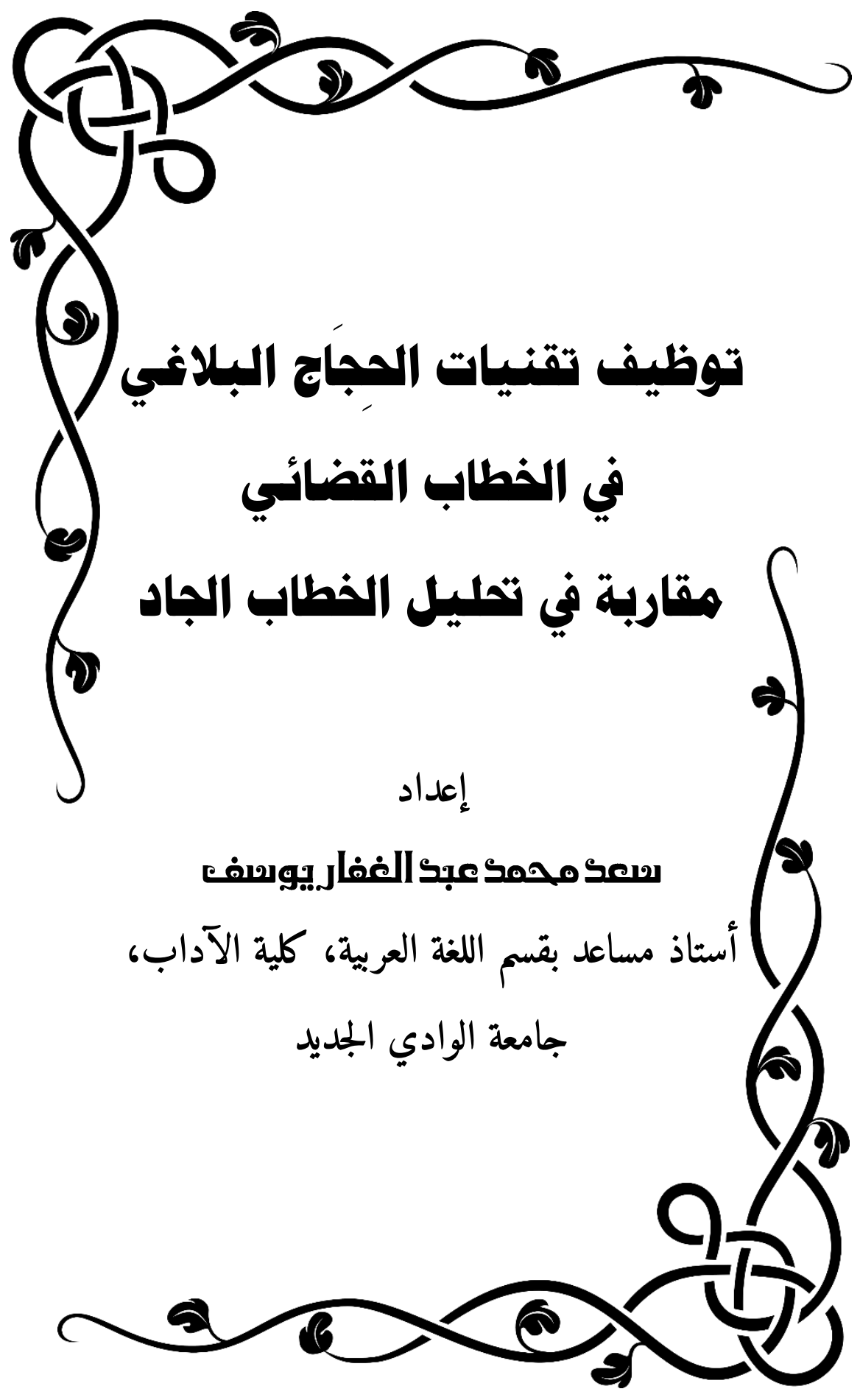


توظيف تقنيات الحِجَاج البلاغي في الخطاب القضائي مقاربة في تحليل الخطاب الجاد 
توظيف تقنيات الحِجَاج البلاغي في الخطاب القضائي مقاربة في تحليل الخطاب الجاد

سعد محمد عبد الغفار يوسف

قسم اللغة العربية، كلية الآداب، جامعة الوادي الجديد، الخارجة، مصر • البريد الإكتروني: saadyousef@art.nvu.edu.eg الملخص : n (المص

يُعـدُّ هـذا البحـث إحـدى المقاربـات في تحليـل الخطـاب الجـاد (الخطـاب القضـائي) مـن منظور الحِجَـاج البلاغي؛ إذْ إنـه يدرس مدى قدرة الآليات

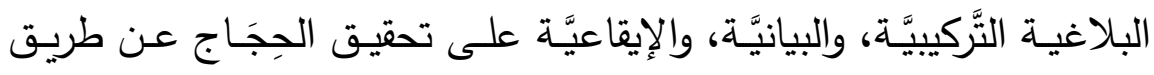

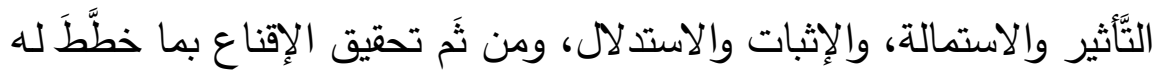
الخطاب من غايات وأهداف. ويهدف البحث إلى استظهار البُعد الحِجَاجي للبلاغـة العربيَّة، وبيان مدى قدرتها على تجـاوز إنتاج الخطاب الخَطسابي

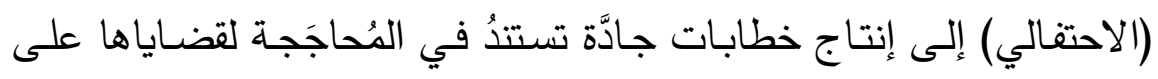
التَّتنيات البلاغيَّة التي تمثِّل استراتيجيات ناجحة في تحقيق غايات وأهداف الخطاب. وقد اعتمد البحث على المنهج الوصفي التَّحليلي، حيث حـاول رصد بعض مظاهر وتقنيات الحِجَاج البلاغي في الخطـاب القضـائي عن طريق تحليله لكيفيَّة اشتغال الحِجَاج بالاستعارة واليُّؤال، والإيقاع، في تحقيق ليق فعل الإقناع في بعض المرافعات القضـائية. ومن أهم النتائج التي توصل فئل إليها البحث:

- بيان الدَّور الذي اضطلعتُ به البلاغة في إنتاج خطاب قضائي ناجح. 


\section{توظيف تقنيات الحِجَاج البلاغي في الخطاب القضائي مقاربة في تحليل الخطاب الجاد}

-مثَّلتِ الاستعارة تقنيةً حِجَاجيَّة وبنيةً إقناعيَّةَ في معماريَّة الخطاب القضائي تبلورتُ بموجبها بعضُ الأدلة التي اقتضاها سياق الخطاب. - مثُّلَ أسلوبُ السُّؤال تقنيةً حِجَاجيَّةً مهمـة في الخطاب القضـائي كرَّست بشكل واضح لإدانة المتهم في سياق الاتهام.

-شكَّلَ الإيقاع - في الخطاب القضائي- وسيلةً مكرَّسةً بقوة من أجل تحقيق التَّأثير والاستمالة على المستوى العاطفي (الباتوس Pathos) الذي يُعنَى بكلِّ ما له صلة بنوازع المخاطَبين (سيكولوجيَّة المتلقي). الكلمــات المفتاحيـةة: الخطـاب القضــائي، الحِجَـاج البلاغـي، الاســعارة، حجاجية السؤال، الإيقاع. 
Employing the Techniques of Rhetorical Argumentation in The Judicial Discourse An Approach to Serious Discourse Analysis

\section{Saad Mohammed Abdel-Ghaffar Yousef}

Department of Arabic Language, Faculty of Arts, New Valley University, Alkhargah, Egypt.

Email: saadyousef@art.nvu.edu.eg

\section{Abstract:}

The present study is an approach to analyze serious discourse (Judicial discourse) from the perspective of rhetorical argumentation. It examines the extent to which the structural, rhetorical mechanisms and the rhythmic rhetorical mechanisms are able to achieve arguments by influencing and coaxing, and by proof and inference. This in turn achieves persuasion of the goals and objectives planned by the discourse.

The study aims to spotlight the argumentative dimension of Arabic rhetoric, and to show the extent of its ability to transcend the production of rhetorical (ceremonial) discourse to produce serious discourses. The argumentation of these serious discourses is based on rhetorical techniques that are considered successful strategies in achieving the goals and objectives of the discourse.

The study adopts a descriptive analytical approach. It tries to observe some aspects and techniques of rhetorical arguments in the Judicial discourse by analyzing how arguments influence others through the use of metaphor, question, and rhythm, so as to achieve the act of persuasion in some legal proceedings. 
Among the most important conclusions of the study:

-The role played by rhetoric in producing a successful judicial discourse is highlighted. Metaphors are argumentative techniques and persuasive structures in the architecture of judicial discourse.

Using metaphors crystallizes some of the evidence required by the context of the discourse. The questioning method represents an important argumentative technique in the judicial discourse, clearly devoted to convicting the accused in the context of the accusation.

-Rhythm - in the judicial discourse - is a means strongly devoted to achieve influence and coaxing on the emotional level (pathos), that is concerned with everything related to the inclinations of the addressees (the psychology of the recipient).

Keywords: Judicial discourse, Rhetorical argumentation, Metaphor, Argumentation of the question, Rhythm. 
بسم الله والحمد الله والصَّلاة والسَّلام على سيدنا محمَّد رسول الله، أمَّا بعد. فإنَّ علاقـة البلاغـة بالحِجَاج قديمـة قِدَم البلاغـة نفسها، ولِيس أدل على ذلك - في البّّياق الغربي- مـن نشـأة البلاغـة اليونانيَّة في سـياق قضــائي، كمـا هـو ثابــت فـي كتـابي (محساورة جورجيـاس) و (القـوانين) لأفلاطون Plato ، وكتابي (البلاغة)، و(فن الثعر) لأرسطو Aristotle

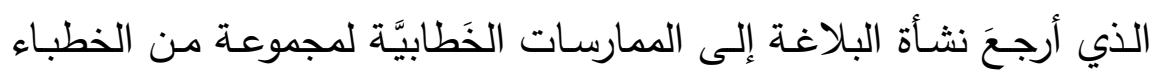
المشـهورين (تسياس Tisias، وكوراكس Corax، وسيراكوز aracuse) الذين برعوا في إقناع الآخرين بوجهـة نظرهم، ومـن ثَم غدتُ ممارسـاتهم

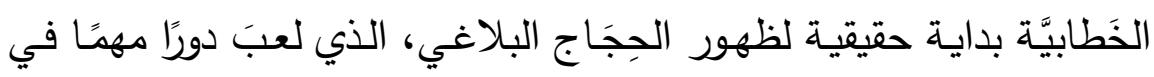

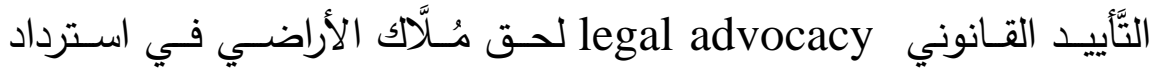
أراضيهم التي صُودِرت من قِبل طغاة صقلية في القرن الخامس قبل الميلاد؛ حيث أعطت البلاغة معنيً للحقوق وصوتًا للقوانين، فحملتُ عبََّ الحِجَاج والإثبات، بوصفها آليةً يتمَّ من خلالها عرض وتمثيل القضـايا القانونيَّة في ساحات المحاكم.

كذلك ارتبط الحِجَاج بالبلاغة العربيَّة منذ وقتٍٍ مبكرٍ من تاريخها؛

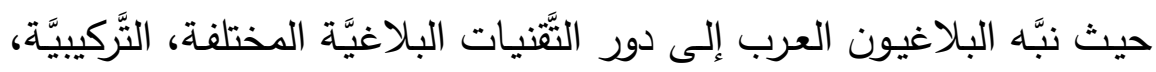

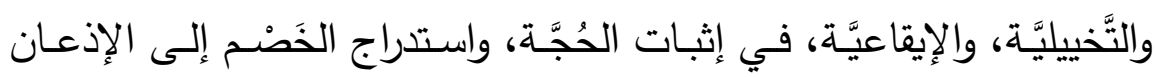

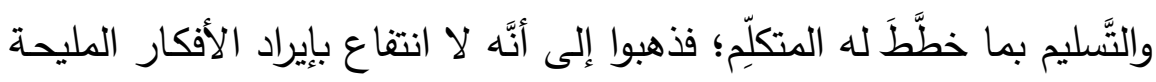

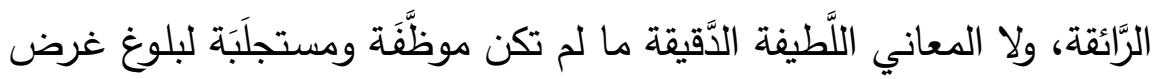

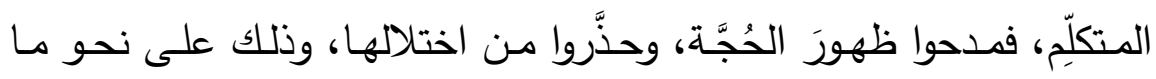




\section{توظيف تقنيات الحِجَاج البلاغي في الخطاب القضائي مقاربة في تحليل الخطاب الجاد}

نجده في البيان والتَّبيين للجاحظ (ت: 00بهـ)، وفي أسرار البلاغة ودلائل الإعجاز للإمام عبد القاهر الجرجاني (ت: الحء هـ).

هذا، ويؤكِد ظهور مصطلح البلاغة الجديدة The new Rhetoric في الإِراسـات الأوروبيَّة - في الأونـة الأخيرة - على مركزيَّة البلاغـة في الممارسـات القانونيَّة Legal Practices، الأمـر الذي يعكس المظهـر الحِجَـاجي للبلاغـة، بــا طرحتـهـ مـن نظريـات، ورؤى جديـدة في تحليـل

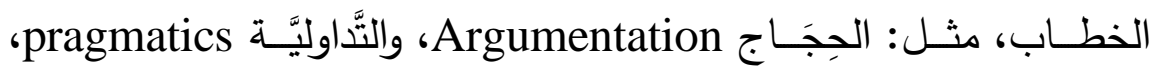
وبلاغة المَّرد Rhetoric of the narrative، وبلاغة العامَّة Rhetoric المستمرة ادِّعاء اليقين - مبنيَّة بقوة على البلاغة، فوراء كل حِجاَج بلاغة . وسوف نعرض في هذا البحث لكيفيَّة اشتغال بعض تقنيات الحِجَاج البلاغي مثل: (الاستعارة، وأسـلوب السُّؤال، وبعض تقنيـات الإيقـاع) في صناعة وصياغة حُجَج الخطاب القضـائي، بقصد الاستدلال على القضـايا التي يعـرض لها الخطـاب، واستمالة المخـاطَبين والتأثثر عليهه، ومـن ثَم إقناعهم بما خطط له الخطاب، وذلك من خلال تحليل نماذج من المرافعات القضائيَّة التي تمَّ تداولها في أروقة بعض المحاكم المصريَّة.

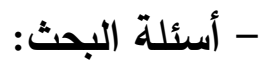
يطرح البحث بعض التَّساؤلات المرتبطة بعلاقة البلاغة بالخطاب الجاد، لا سيَّما الخطاب القضائي، منها : 


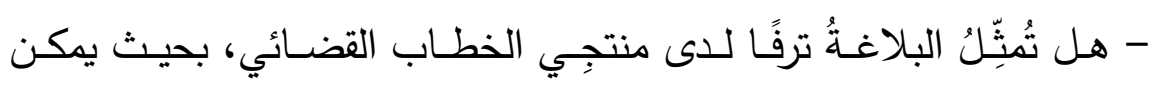
الاستغناء عنها في صياغة خطاباتهم، أم أنها أساسُ من أسس نجاحه في تحقيق مقاصده وأهدافه ؟

- هل يمكن أن تُمَثِلَ التقنيات البلاغية - التَّكيبيَّة، والتَّخييليَّة، والإِيقاعيَّةَ-

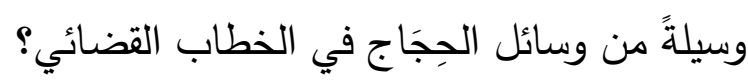
- هل يمكن للبلاغة أن تُكرِّنَ لحِجَاج السُّلطة القضـائيَّة، وما يصدر عنها

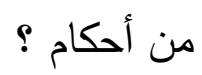

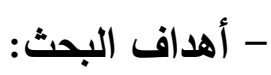

يسعى البحث إلى تقديم تحليل بلاغي لنمـاذج مـن بعض المرافعات

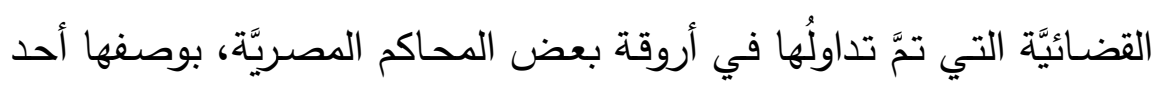
أنماط الخطاب الجاد Serious discourse ؛ بهدف بيان الأثر الحِجَاجي لبعض التَّتنيات البلاغيَّة في تحقيق فعل الإقناع والتأثير على المخاطبين، وتسعى الدراسة في هذا الصَّدد إلى تحقيق مجموعة من الأهداف أهمها: - محاولةُ استظهار البُعد الحِجَاجي للبلاغـة العربَّة التي اتُهِهـتُ بالعنايـة بالخطاب الاحتفالي دون الخطاب الجاد. - بَيانُ الدَّور الذي تضطلحُ بـه البلاغـة في إنتاج خطاب قضـائي نـاجح يستندُ في المُحاجَجة لقضاياه على الثَّنَيات البلاغيَّة. - بيانُ مدى نجاح البلاغـة العربيـة في تجـاوز إنتاج الخطـاب الخَطـابي (بفتح الخاء) إلى إنتاج خطابات جادَّة ذات استراتيجيات ناجحة في تحقيق أهدافها. 
- يسعى البحث أن يكـون أحـد روافـد التَّأسيس النَّظري والتَّطبيقي لتحليـل الخطاب القضائي من منظور الحِجَاج البلاغي.

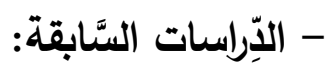

غَدتُ بلاغة الخطاب القضـائي حقَلًا معرفيَّا لـه مشروعيته، لا سيَّما بعد كلِّ هذه المقاربـات في تحليل الخطاب الجاد (البّيّاسي، والاقتصـادي، والعسكري ...إلخ) التي تزخر بها الأقسام الأكاديميَّة في كثير من جامعات أوروبـا وأمريكا، وتُعنَى بها بعض الأقسام الأكاديميـة في جامعاتتـا العربيـة على استحياء.

ولم أقف - على حدّ علمي - فيما طالعتُ من دراسـات وبحوث على في

دراسة متخصصة تتاولت الحِجَاج البلاغي في الخطاب القضـائي في الذَّرس العربي الأكاديمي -حتَّى وقت هذه الدراسة- لحداثة هذه المعالجة في تحليل الخطـاب القضـائي، وقد كان ذلك مـن الصـوبات التي واجهتي في هذه الدراسة، حيث لا تتوفَّر مراجع أصيلة في موضوع الدراسة.

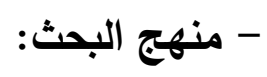

اعتمد البحث على المنهج الوصفي التَّليلي، حيث حاول رصد بعض

مظاهر وتقنيات الحِجَاج البلاغي في الخطاب القضـائي عن طريق تحليله لكيفيَّة اشتغال الحِجَاج بالاستعارة، والسُؤال، والإيقاع، في تحقيق فعل الإقناع في بعض المرافعات القضائَّةَ.

وقد جاء البحث موزَّعًا على مبحثين: مبحث نظري، ومبحث تطبيقي

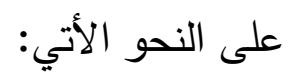


- المبحث الأول: الحِجَاج البلاغي في الخطاب القضائي (إطار نظري). - المطلب الأول: في مفهوم الحِجَاج البلاغي. - المطلب الثَّاني: مفهوم الخطاب القضائي. - المطلب الثَّلث: النِّمات الرَّئيسة للخطاب القضائي. - المبحث الثَّاني: تقنيات الحِجَاج البلاغي في الخطـاب القضـائي (نماذج تطبيقيَّة).

المطلب الأول: حِجَاجيَّة الاستعارة. - المطلب الثَّاني: حِجَاجيَّة السُؤال. - المطلب الثَّالث: الحِجَاج الإيقاعي. - خاتمة بأهم نتائج البحث. - قائمة المصادر والمراجع. 
المبحث الأول

الحِجَاجُ البلاغي في الخطاب القضائي

(إطارُ نظـريُّ)

ليس الحِجَاج Argumentation قصرًا على خطاب دون خطاب،

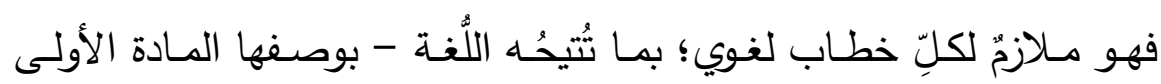
للإقنـاع - مـن طـرق الاسـتدلال، واسـتراتيجيات الإقنـاع الملائمــة لجميـع سياقاته. والخطاب القضـائيforensic Discourse وفق هذا المعنى هو

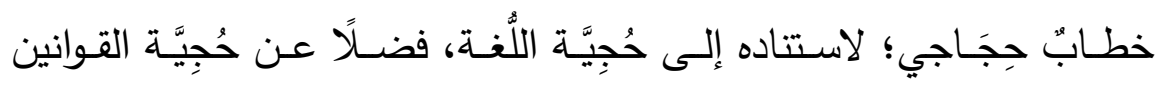

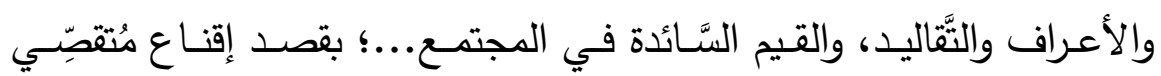
الحقائق بإدانة أو تبرئة المدَّعَى عليه.

هذا، ويُمَثِّلُ الحِجَاج البلاغي Rhetoric Argumentation أحد أنماط

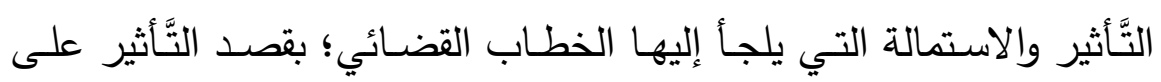
مواقـف وسـلوكيات مخاطبيـه. وسـوف نعـرض في هـذا الإطـار النَّــري لمفهومي الحِجَاج البلاغي، والخطـاب القضـائي، ثم نختم بالَِّمات الرَّئيسـة للخطاب القضائي.

المطلب الأول

\section{في مفهوم الحِجَاج البلاغي}

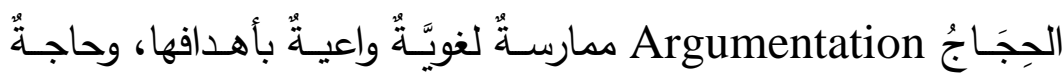
تواصليَّةٌ، نلجأ إليها في كلِّ شؤون حياتتا: في البيت، والعمل، وقاعات الذَّرس،

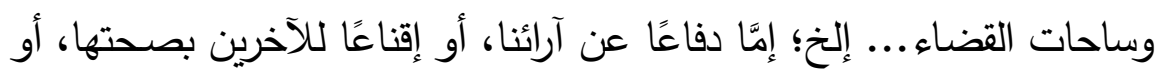
تبريرًا لبعض أفعالنا ...إلخ. ومن ثََّّ فهو - من هذه الجهة - تداوليُّ وظيفيُّ، 


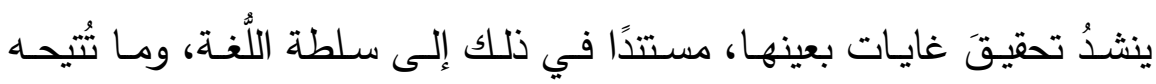
للناطقين بها من تقنيات حِجَاجيَّة.

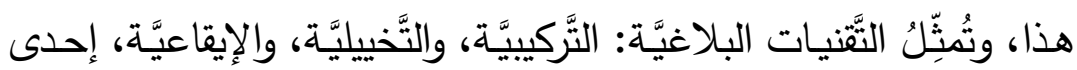

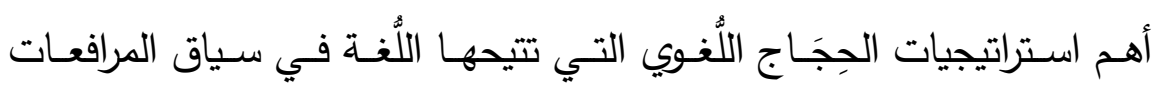
القضائيَّة، وهو ما التثتَ إليه أرسطو في تعريفه للبلاغة بأنَّها " فنُ الإثبات في سي

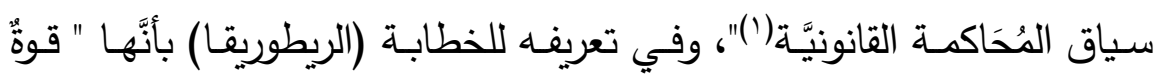

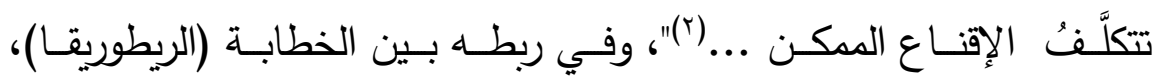
وصناعة الجدل (الديالقطيقية) بوصفهما يرميان إلى شيءٍ واحدٍ هو الإقناع(r) الأي يؤدي بدوره إلى تغيير في توجهات، وآراء، وسلوك الآخرين. ويبدو أنَّ شاييم بيرلمسان Chaim Perelman ، ومساعدته أولبرخت - تيتكا Olbrecht - Tytica كانَا شَاخصَيْنِ في تعريفهما للحِجَاج إلى تعريفي أرسطو السَّابقَيْن للبلاغـة والخطابة، حينما عرَّفَا الحِجَاج بأنَّهَ " جملة الأسـاليب التي تَضـطلحُ في الخطـاب بوظيفـة حمـل المتلقي على الاقتنـاع Conviction

ا-سلوان، توماس أ : موسوعة البلاغة، ترجمة نخبة، إثراف وتقديم: عماد عبد

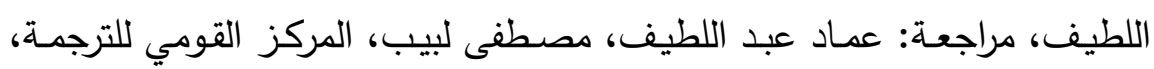

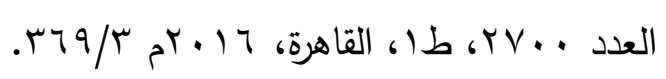

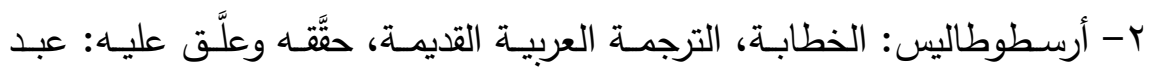

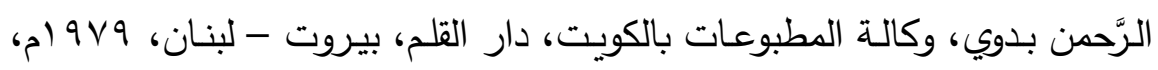
ص 9. ץ- راجع: المصدر السابق نفسه: صץ. 


\section{توظيف تقنيات الحِجَاج البلاغي في الخطاب القضائي مقاربة في تحليل الخطاب الجاد}

أساسيَّة، هي الفعل في المتلقي على نحو يدفعـه إلى العمل أو يُهِيِّّهـ للقيام

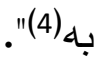

ويُمثِِّلُ الحِجَاج من وجهة نظر بيرلمان Perelman ، وتيتكا Tytica

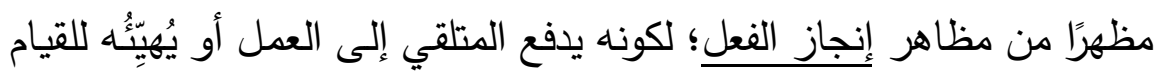

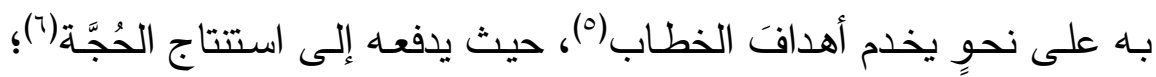
ولذلك كان نجاح الحِجَاج البلاغي، متوقفًا - في جزْه منه- على قوة التَّثَثر المَبنيَّة على الخبرة في الإثبات، والاستدلال، وابتكار الأدلة التي تحقق بدورها اقتناع المخاطَبين بأشياء لم تكن في قناعاتهم من قبل. لإبل وتُعدُّ البلاغـة - بمـا تمتلكـهـه مـن قدرة كبيـرة على التَّأثير والاسـتمالة، والإثبات والاستدلال والمبالغة في أداء المعنى(V) عبر طاقاتها التَّببيريَّة الهائلة - إحدى آليات الحِجَاج الناجح الدالة على تَلُشُس الحِجَاجي العقلي بالجمالي المُمتِع، فهي " ليست محصورة في البُعد الجمالي بشكل صـارم، بل تتزعُ إلى بلى

4- Argumentation, Chaim Perelman Tyteca, Rhetoric: A Treatise on The New

France, 1969, v1, p. 92.

5 - p. 92 Rhetoric: The New

צ- راجع: صولة، عبد الله : الحِجَاج أطره ومنطلقاته من خـلال مصنف الحِجَاج،

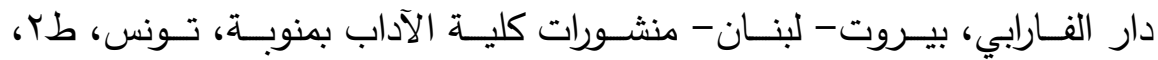

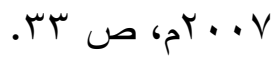
V- راجـع: السَّكاكي: مِفتاح العلوم، ضـبطه وكتب هوامشـه وعلَّق عليـه: نعسيم

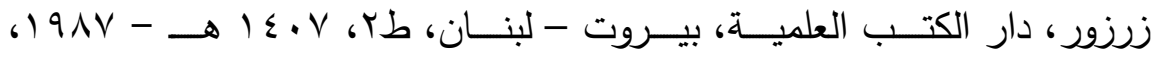

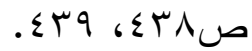


أن تصبح عِلمًا واسعًا للمجتمع (^)"، وهذا ما أكَّده جورج لاكوف G. Lakoff، وجونسون Johnson عام • ^1 ام في كتابهما المهم " الاستعارات التي نحيا بها Metaphors We Live By "؛ ولذلك استمرَّ النظر إليها قرونًا طويلة

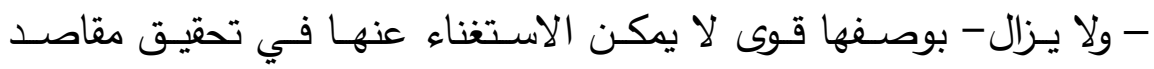

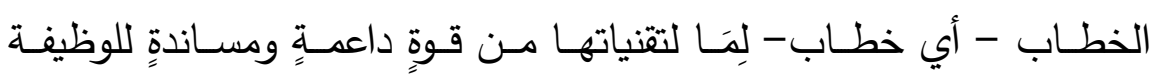
البرهانيَّة الاستد لاليَّة للخطاب(9)؛ وهو مـا فَطنَ إليـه الجـاحظ (ت:

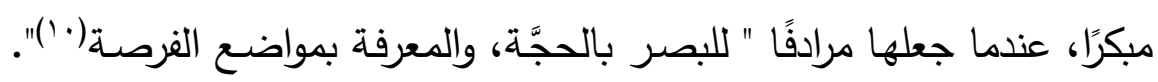
الأمر الذي يعني أنَّنا لا يجب أن ننظر إليها بوصفها تَرفًا أو خيارًا يأخذه

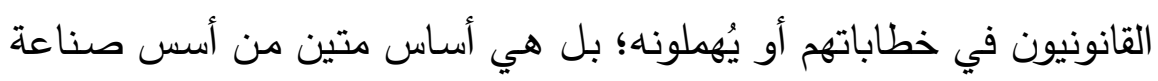

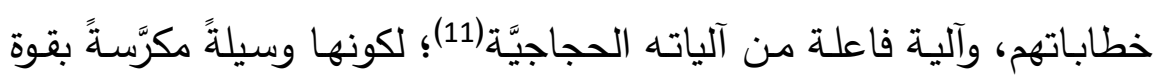
مـن أجـل تحقيـق التَّأثير والاسـتمالة على المسـتوى العـاطفي (البـاتوس (Pathos الـذي يُعنَّى بكـلِّ مـا لـه صـلة بنـوازع المخـاطَبين (سـيكولوجيَّة

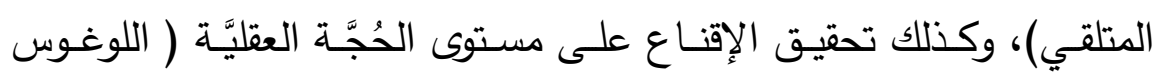

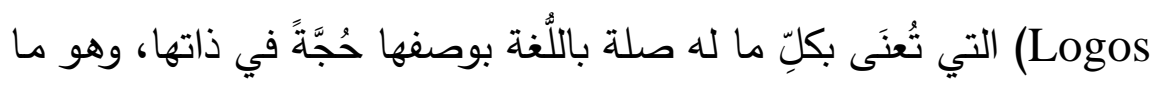

1-بيلت، هنـريش: البلاغـة والأسـلوبيَّة، ترجمـة وتقديم: محمد العمـري، إفريقيـا

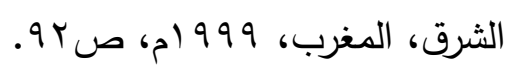
9- وليس أدل على ذلك من اشتغال بعض فنون البلاغـة بهذا المعنى، أمثال: حسن التعليل، والمذهب الكلامي، والتثبيه الضِّمني.

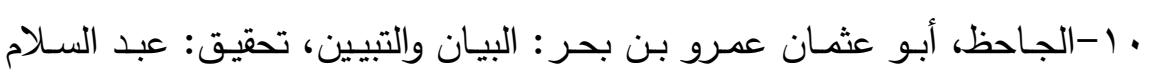

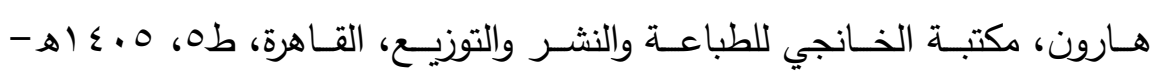
$.94 / 1$ ، 91910

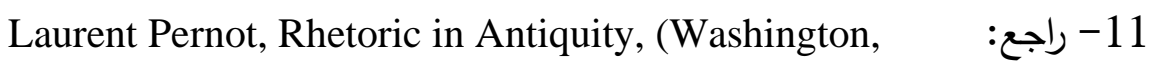
D.C: The University of America Press, 2005), 190. 
يعني أنَّ الخطاب الحِجَاجيَّ يُقِوِي طرحَه بالاعتماد على الأسـاليب البلاغيَّة

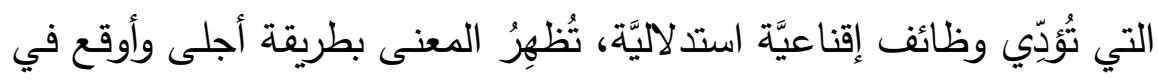

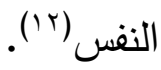

هـذا، وقـد يَتلبَّنُ الحِجَاجُ - فـي كثيـر مـن الأحيـان - بزخـرف القـول

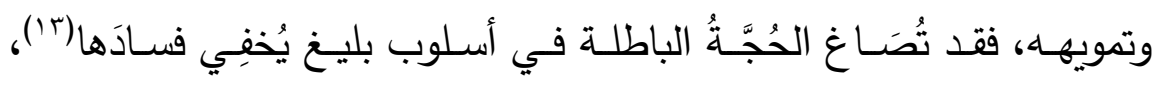
فتُحدِثُ بجمـال إحكامهـا، وحسن صـياغتها وعرضـها، وقوة تأثيرهـا حِجَاجًا

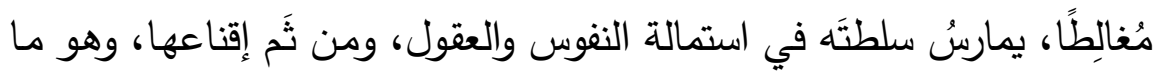

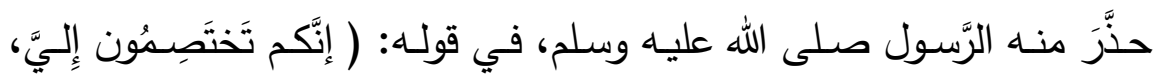

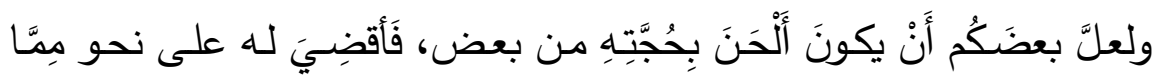

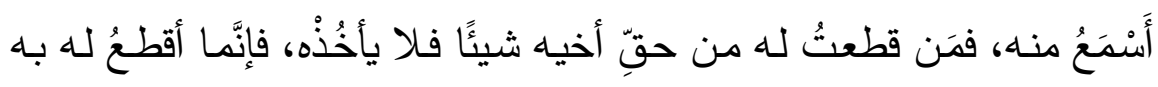

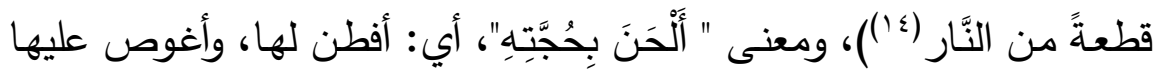

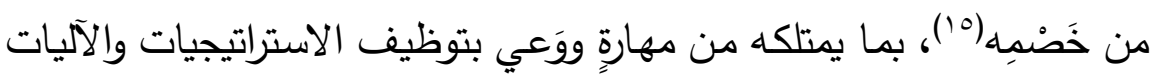
اللُّوية والبلاغيَّة المؤثِّة في المخاطَب، أكثر من حِيازته للحقِّ والحقيقة، الأمر الذي قد يترتبُ عليه إبطالُ حقّ.

r ا - راجع: الحباشة، صابر : التداوليّة والحجاج: مداخل ونصوص، دار صفحات

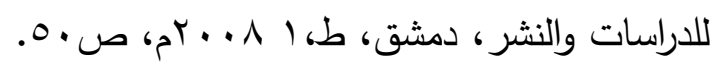

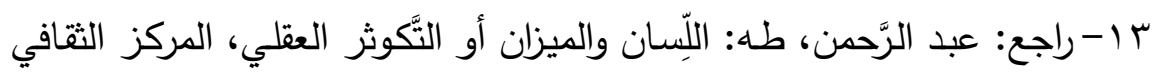

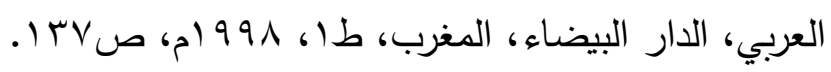
ع ا - النَّووي، أبو زكريا محيي الدين يحيى: شرح صحيح مسلم، دار إحياء التراث

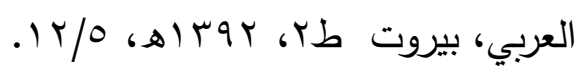

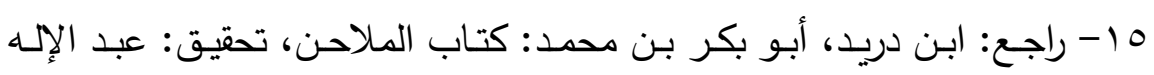

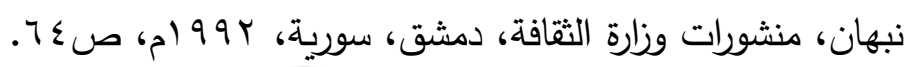


المطلب الثَّاني

الخطاب القضائي: مفهومه،، وسماته

1 - مفهوم الخطاب القضائي forensic Discourse :

الخطاب Discourse تواصلٌ لغوي يجري بين متكلِّمٍ ومستمعِ في سياقٍ

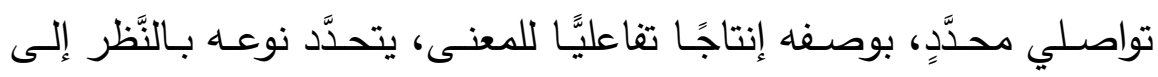

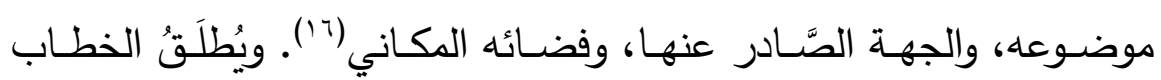

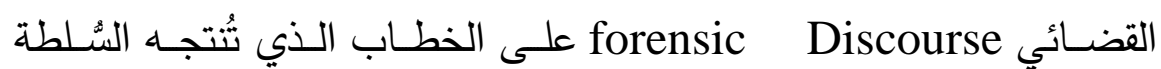
القضائيَّة في جلسة قضائيَّة تُحدَّدُ زمانًا ومكانًا من قِبَل الهيئات المختصَّة....، وهو من حيث الوظيفة يهدف إلى إقناع المخاطَبين بتحقيق العدالة(17)، أمَّا من حيث الجهة التي يصدر عنها، فهو خطابُ مُؤسَّسي جاد، يصدرُ عن من المؤسسـة القضـائيَّة، أو النيابـة العامِّة، أو مُمثلي الدِّفاع، ولا يُعـدُّ حديث

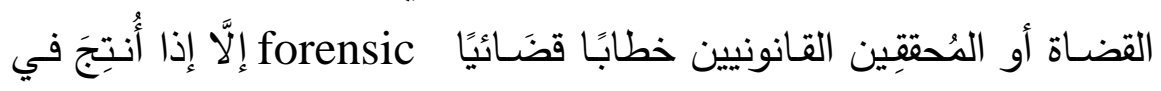
سياق Context (فضاء) تواصلي محدَّدٍ، مثل: قاعات المحاكم، أو قاعات

7 ا-راجـع: ميلز، سـارة : الخطـاب، ترجمـة:عبد الوهـاب علوب، المركز القومي

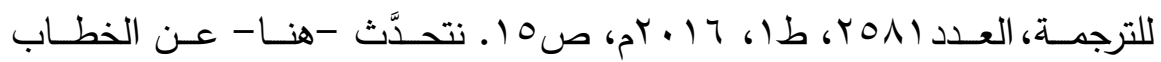
المنطوق؛ لأنَّهـ "ضـن المعنى "السيميوطقي" الواسع قد يثير الخطاب -أيضًا-

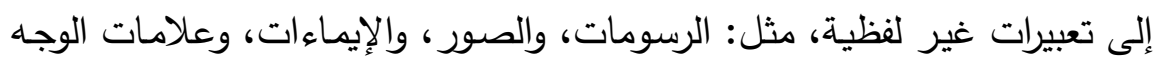

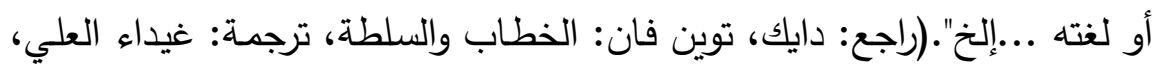

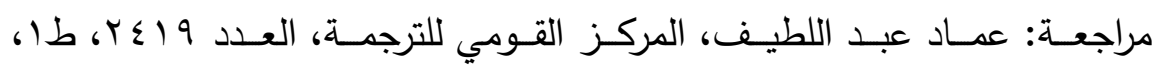

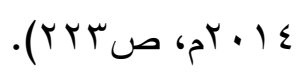

17 - Bitzer, Lloyd. The rhetorical situation. Philosophy and Rhetoric, 1968, 1: 1-14. 
التَّحقيقات القانونيَّة / القضـائيَّة؛ لأنَّ النَّصَّ وَحْدَه لا يُمكنهـه أن يُحدِّدَ هُويَّة الخطاب القضَائي بشكلٍ حاسم، وإنَّما يتدخل في ذلك سياقُ الخطاب وفضاؤه

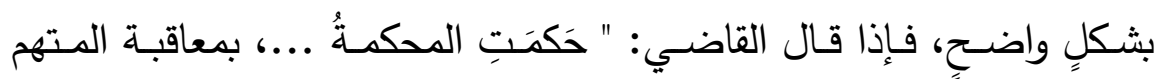
بـالحبس سـنة مـع الثـخل والنفـاذ"، فـإنَّ هـذه الجملـة مـن خطابـه (حكمـبِ المحكمةُ) ليس لها معنئ إلَّا إذا قِيلتُ في سياق قضائي بعينه (يقضي باتباع إجراءات بعينها)، ووَقَعَتْ في فضـاء مؤسسي محدد (هو قاعـة المحكمـة)،

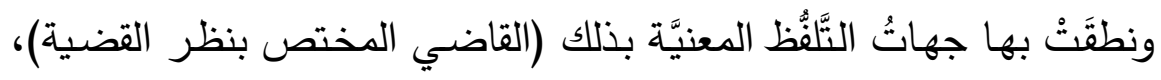
بوصفه السُّلطة المخوَّلَة بإصدار الأحكام؛ ولذلك تخرجُ هذه الجملة من حيز الإخبار إلى نطاق أفعال الأحكام verdictifs actes، أو أفعال الكـلام

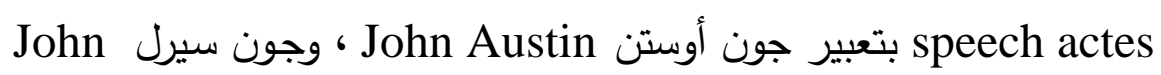
Searle

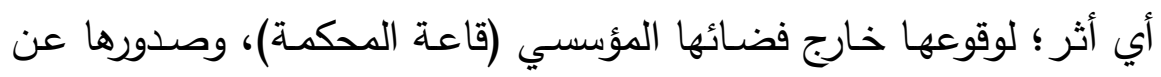
غير ذي صفة.

وإذا كان الخطيب حَائزًَا للمُّلطة قبل التَّلُّْظ في حال الخطاب القضَائي،

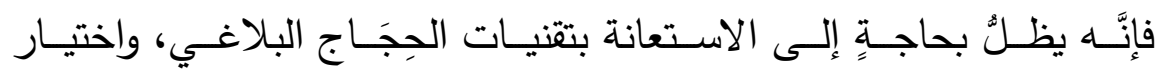

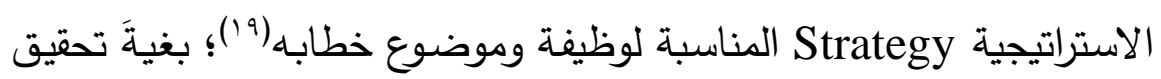

11- وهو ما يعني أنَّ أحد أجزاء النَّص قد يمثل فعلًا من أفعال الكلام. راجع:

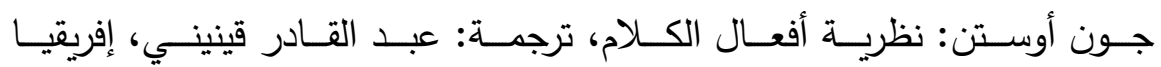

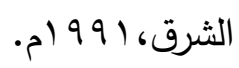
9 1 - راجع: دايك، فان : النَّص والنِّياق، استقصساء البحث في الخطاب الدلالي

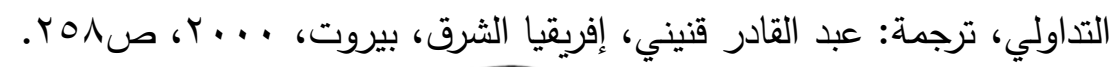


مقاصـد وغايـات خطابـ(··) وهو مـا يَعني أنَّ البلاغـة تُسههم في التَّكريس

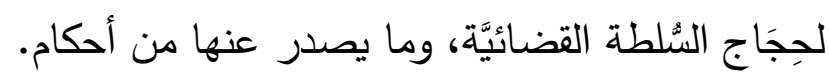

وإذا كان خطاب النّيّابـة العامَّة يهدفُ في بعض القضـايا إلى تبشيع

الجرائُ وتهويلها وبيانِ حجم الاعتداء، وانحطاطِ الأخلاق، وخرق القوانين... إلخ؛ بقصد استتكار الجريمة وإثبات التُّهمة على المتهم...؛؛ لتتتهي إلى الحُكم

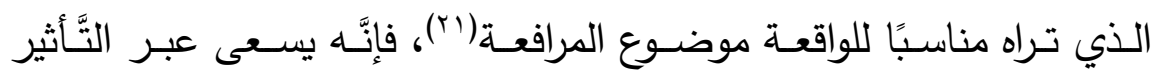

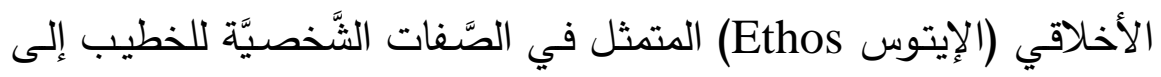

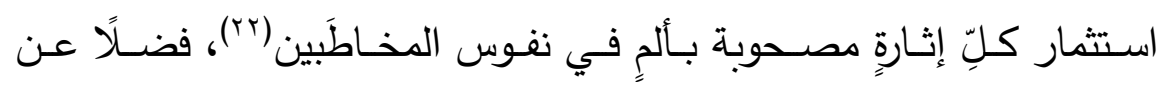

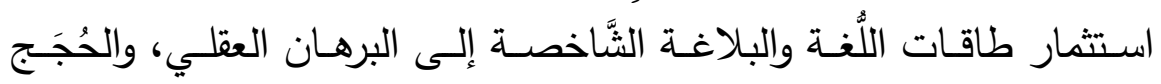

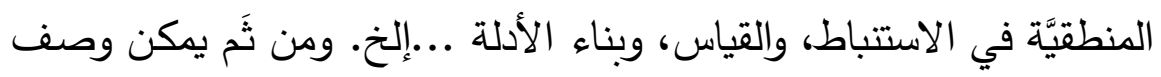
خطاب النيابة العامة بأنَّه خطاب حِجَاجِي تأثيري بالدرجة الأولى، يَعِي جيدًا

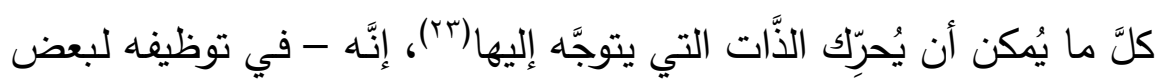

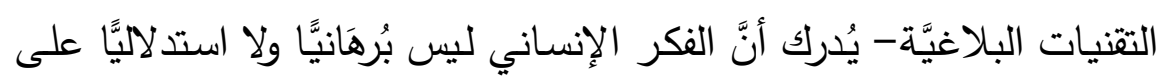

• ץ- راجع: البهلول، عبد الله : الوصـايا الأدبيَّة إلى القرن الرابع هجريـا، مقارنـة

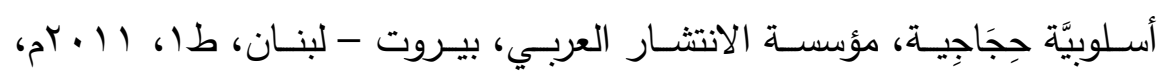
صع שח، סדז. اب- ينبغـي أن نثـير هنـا إلى أنَّ مرافعـة النيابـة (الادعـاء العـام) ينـدرج تحت خطاب السُّلْة. Y Y - يـرى أرسطو أن هنـاك ثلاثتة أسس للحجـج البلاغيـة في الخطـاب، هـي:

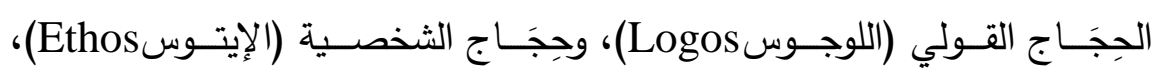

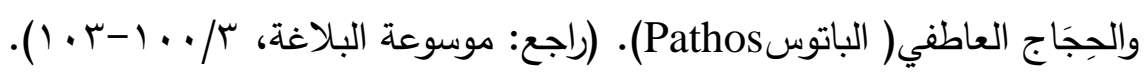

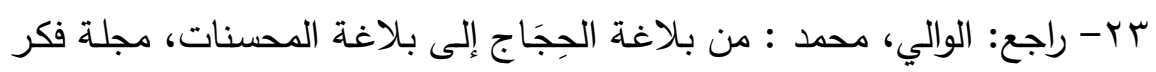

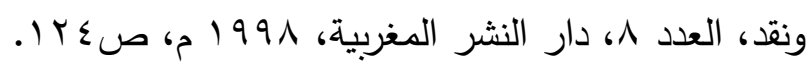




\section{توظيف تقنيات الحِجَاج البلاغي في الخطاب القضائي مقاربة في تحليل الخطاب الجاد}

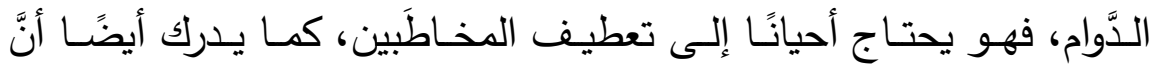
حِجَاجَه وتأثيره يظلُّ ناقصًا إذا ما خلا من تأثيرات الحُجَج العقليَّة والمنطقيَّة. أمَّا خطابُ الدِفاع فيلجأ عادةً إلىى الحِجَاج العاطفي الثَّاخص إلى إثارة استعطاف هيئة المحكمة، وتهيئتها للشفقة والرَّحمـة على موكله عن طريق إقناعها بقساوة الظروف المحيطة به، وانعدام القصد والنّيـة Intention (عَ) في اقتراف الجريمـة، وذلك عن طريق سَوق مجموعـة من الحُجَجِ المكتنزة

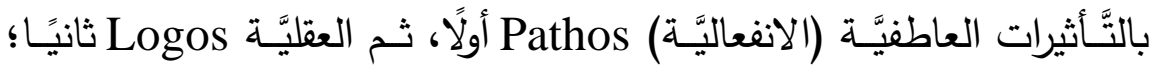
ولذلك أدرك القانونيون جيدًا " أنَّ البلاغة صفة لازمة لَّن جعل الدِّفاعَ عن الناس مهنتَه، واصطلحوا على وجوب أن يكون المحامي - أو عضو النّيابة العامَّة - فصيحَ اللّسّان، بالغَ الأثر بكلامهـ، متلاعبًا بالعقول والقلوب معًا!، وما يزال الإجماع على لزوم توافر هذه الصِّفات واقعًا(ror). r - سمات الخطاب القضائي :

ينشـدُ الخطاب القضـائي forensic Discourse تحقيقَ العدالة من خلال التَّركيز على إثبات الأدلتة، والتتبؤ بحُجـج الخصوم، وتفنيدها، والرَّد عليها...، عـن طريـق اسـتعمال مجموعـة مـن الاسـتراتيجيات التي تسـى تهى لتحقيق أهدافه وغاياته، شأنهه في ذلك شأن كل خطاب موجَّه، فهو خطابٌ :

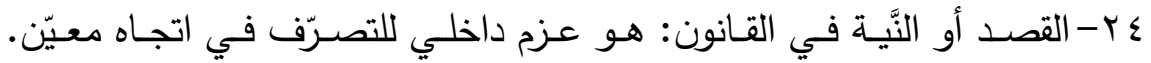

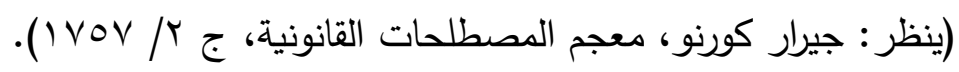

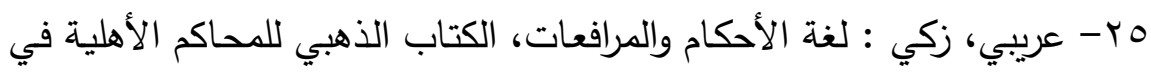

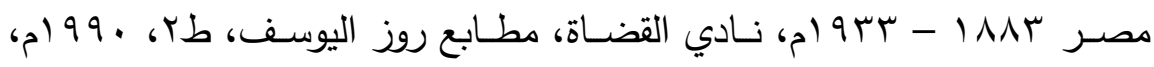

$$
\text { ص ص ص الما. }
$$


- مؤسسيُ تواصلي، يُمنِّلُ مظهرًا من مظاهر المُمَارسَة المؤسساتيَّة للغة. - وَظيفيُ، شَاخصُ إلى تحقيق العدالة، ثري بالمصطلحات القانونيَّة. - مُخَطَّطُ له، مبنيُّ على استراتيجية تنشد تحقيق أهدافه ومقاصده. - يكتسبُ صفتَه القضائيَّة من مُنتِجِه، ومُلقِيه، وفضَائه المكاني المُحدَّد. - يُمَثِلُْ شَكلًا من أشكال ممارسة السُّلطة.

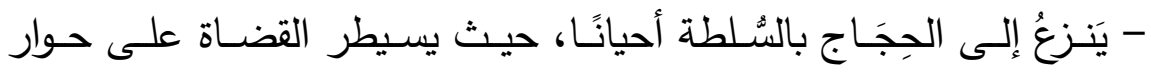
المدعَى عليهم، والثهود، والدفاع أيضًا. - تحضر الأفعال التَّوجيهيَّة Directive acts فيه بقوة. - إقناعيُّ حِجَاجي، يعتمد على صناعة الحجَّة، يُعنَى بالوظيفـة الحِجَاجِيَّة؛؛

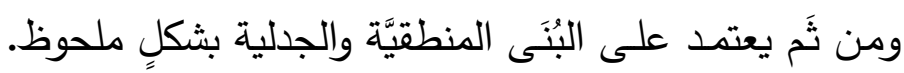

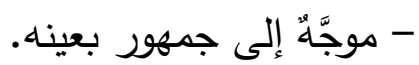

- تتنوعُ استراتيجياته بتتوع موضوعه، بقصد إنجاح العملية الحِجَاجِيَّة. - لا يقتصر على التأثير والبرهان فقط، بل يتعداه؛ ليصل إلى درجة التوجيه والإصلاح.

r- تحليل الخطاب القضائي Forensic discourse analysis : يُعدُّ تحليل الخطاب Discourse analysis بصفة عامَّة حقلًا بينيَّا، يتحرَّك في مناطق اهتمام مجموعة من العلوم - بوصفه ممارسـة اجتماعيَّة

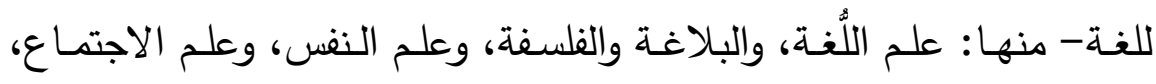


وإثنوغرافيـا التواصـل، وغيرهـا مـن العلـوم(بr) التـي تُعنَى بوصـف النَّص، وتحاول تقديم تفسير للعلاقة بينه وبين مجال التفاعل معه، ثم تعرض للعلاقة

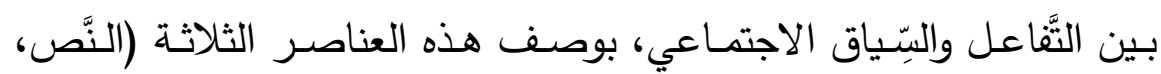
والتَّاعل، والنّيّاق الاجتماعي) هي عناصر الخطاب(rV). ومن هذا المنطلَق سوف يكون تحليلنـا للحِجَاج البلاغي في الخطـاب القضــائي شاخصًا إلى الى الاهتمـام بـالنَّص، مـع بيـان كيفيَّة اشتغال بعض تقنيـات الحجـاج البلاغي (الاستعارة، والسؤال، والإيقاع)؛ في تحقيق أهداف وغايات الخطاب بالنظر إلى سياقه وفضائه، بوصفه خطابًا مؤسسيًّا، له أدبياته، ومعاييره المؤسسيَّة.

van Dijk.T.(2007). (ed) discourse studies. sage

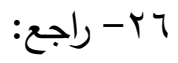
benchmark series. new Delhi; sage, vol 1, p 7-27. VV

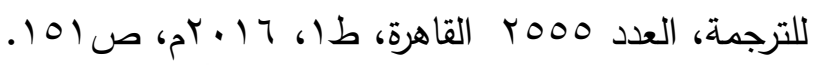




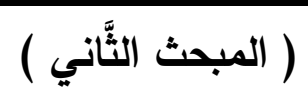

تقنيات الحِجَاج البلاغي في الخطاب القضائي

(نماذج تطبيقيَّة)

ظلت البلاغة جزيًا مهمًا من الممارسة القضـائيَّة والقانونيَّة على مدى

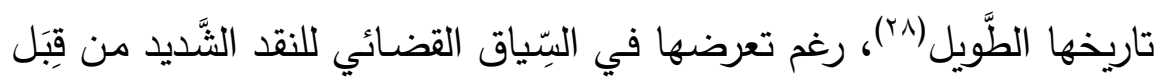

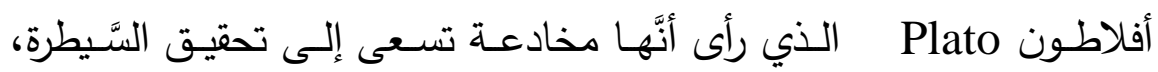

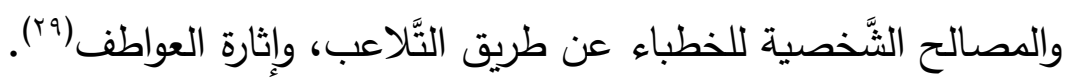
وسوف نعرض في هذا المبحث لاشتغال بعض تقنيات الحِجَاج البلاغي

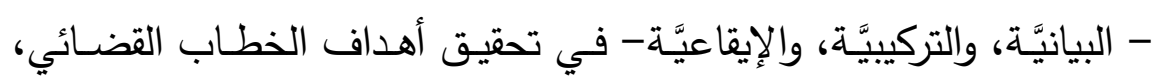
وذلك من خلال التَّطبيق على نماذج من بعض الخطابات القضائيّة.

George A. Kennedy, Classical Rhetoric \& its

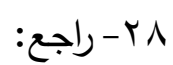
Christian and Secular Tradition from Ancient to Modern Times, (Chapel Hill: The University of North Carolina Press, .1999), 20-21

q ب- ربط أفلاطون البلاغـة بمراوغة ومغالطـات السوفسطائيين Sophists الذين

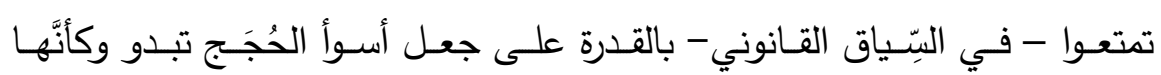
الأفضل، في الوقت الذي ينبغي فيه للقانون أن يقيد الحكم بتقديم الدليل والبرهان.

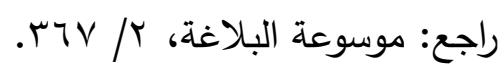




\section{المطلب الأول}

\section{حِجَاجيَّة الاستعارة}

\section{(استعارات الفوضى - نموذجًا)}

Persuasion يسعى الخطاب القضـائي إلى استثمار سُبْل الإقناع والبرهان القانوني (الثهود، والعقود، والقوانين، والقَسَّ ...)، كما يسعى بنفس التس

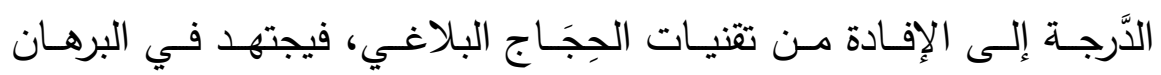
والاستدلال عن طريق القوة الحِجاجيَّة لبعض الصـور البيانيَّة التي تؤدِّي

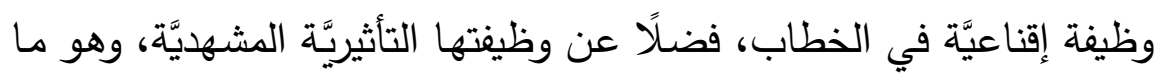
التََتَّ إليه بلاغيو اليونان قديمًا، حينما استخدموا الاستعارة " لإحداث تغيير في الموقف الفكري أو العاطفي للمتلقي (·r)"، بعيدًا عن رطانة القانون. كمـا أدرك البلاغيون العـرب أنَّ حِجَاجيَّة الاسـتعارة تكمـن في كونها

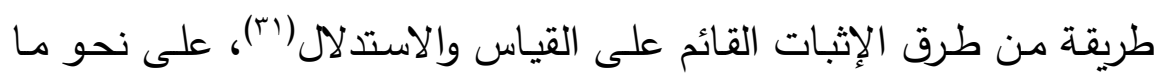

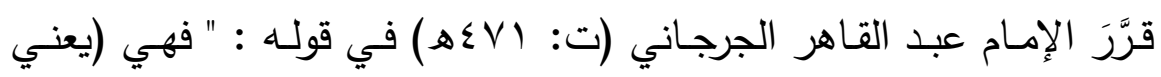

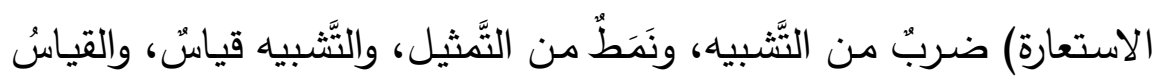

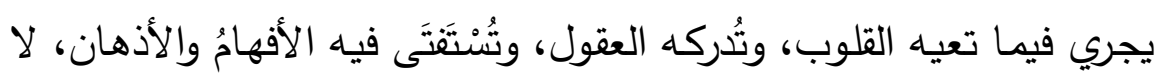
الأسماع والآذان(rr)". هذا، فضلًا عن كونها طريقة من طرق الإثبات القائم

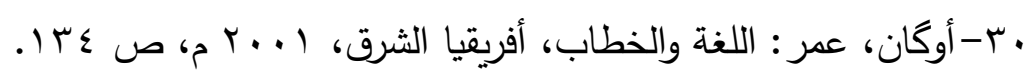

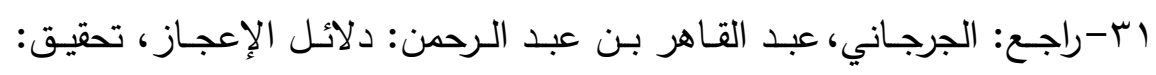

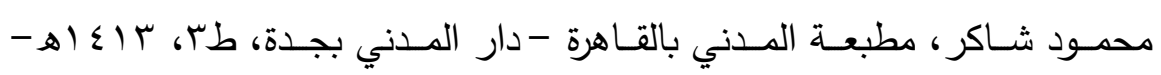

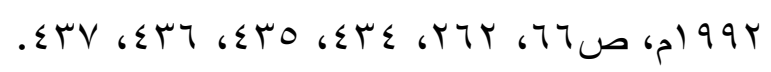

Yr- الجرجاني: أسـرار البلاغـة، قرأه وعلق عليه: محمود شـاكر ، مطبعة المدني

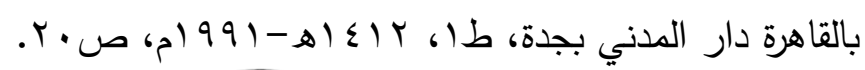


على الاستدلال " يكونُ القصْدُ بالإثبات فيها إلى معنَّى ليس هو معنى اللَّظظِ،

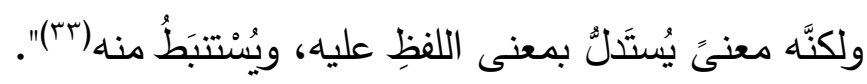

وقد لا تستقيُمُ الحُجَّةُ، ولا يتضـحُ معناهـا، وينكشفتُ مغزاهـا إلَّا إذا

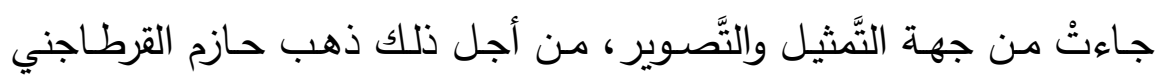

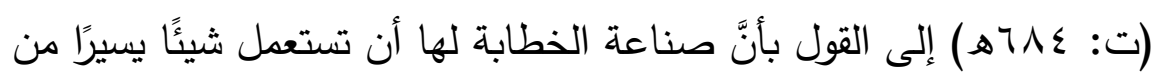

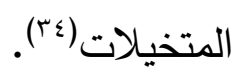

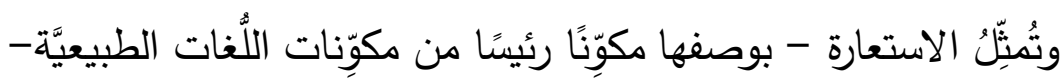

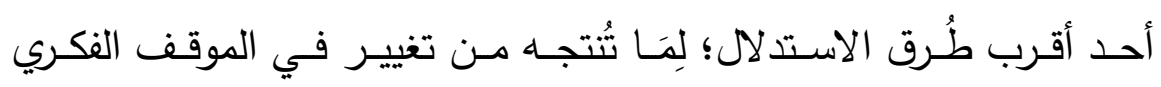
والعاطفي للمتلقي عن طريق ما تُولّدهد في نفسـه من معرفة تأتيهـ من جهـة

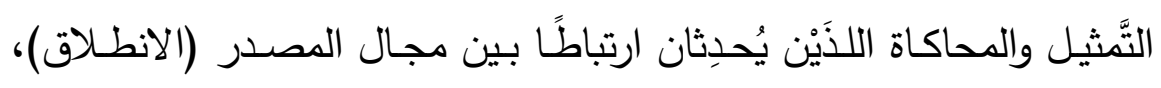
ومجال الهدف (الوصول) وهو ما يجعل منها تقنية حِجَاجيَّة باقتدار.

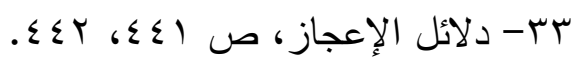
ع ب- القرطاجني، أبو الحسن حازم بن محمد: منهاج البلغاء وسراج الأدباء، تقديم

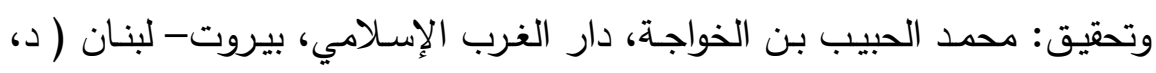

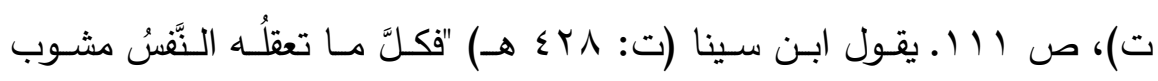
بتخيل"، ولذلك يذهب طله عبد الرحمن إلى أنـه: "لا حِجَاج بغير مجـاز "، الأمـر

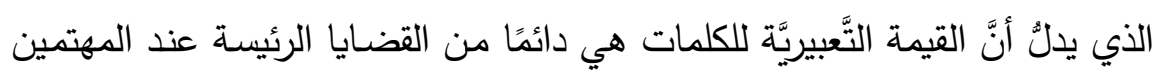
بلغة الإقناع. راجع: ابن سينا، أبو علي الحسين بن عبد الله: التعليقات، حققه وقدَّم

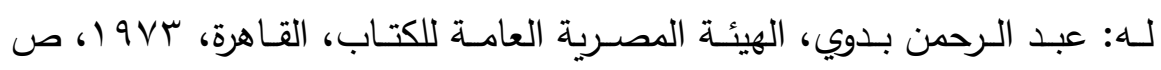

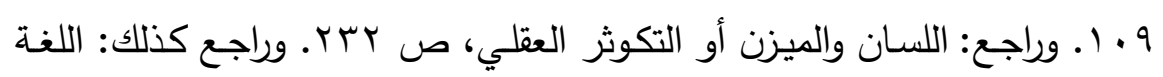

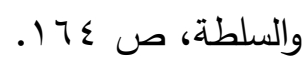


وينبغي أن يكون الحِجَاج البلاغي مبنيَّا على وضسوح الأدلـة اللُّويَّة Linguistic evidence

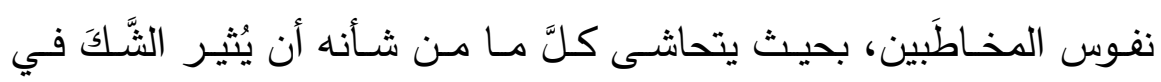
نفوسهُ؛ ليترك لديهم انطباعًا بالثِّقة في أدلته الإثباتيَّة. ونسوق في هذه المقاربـة التَّحليليَّة للخطاب القضـائي (بَّ) نموذجًا مـن مرافعـة النِّيابـة العامَّة يعكس براعتها في الاعتمـاد على مرتكزات الخطاب

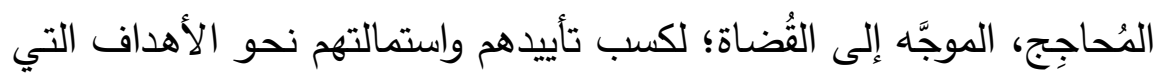

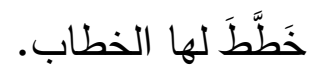

هذا، وسوف تعتمد النّيابـة في خطابها على توظيف مجموعـة من الاستعارات المفاهميَّة

هـ- المصداقيَّة مسألة مهمـة في كلِّ جوانب الخطبة، كأن يقول الخطيب في المحاكمة إنه أحسَّ بعبء أخلاقي أجبره على قبول هذه القضية، وليس لأي هدف

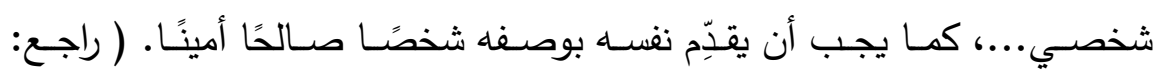

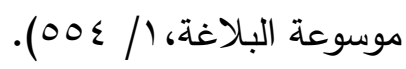
جب- لن نعرض هنـا للخطـاب القضـائي المكتوب، ونقصد بـه القوانين، والعقود، واللوائح ...إلخ. TV متواريـة خلف صـورة بيانيـة، يمكن استتباطه مـن أكثر مـن استعارة، مـن شـأنه المسـاعدة في تفسير غمـوض أطـراف الصـورة البيانيـة. راجـع: Metaphor Analysis Critical to Approaches Approaches-Jonathan .CharterisLondon, 2004, Pe 15 


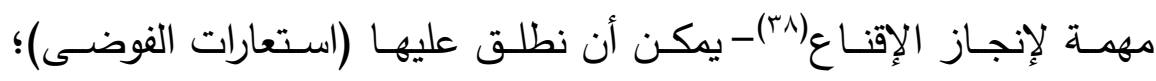
لارتباطها بالتَّدليل على الفوضسى التي أحدثها ديوان (الغاياتي) يومئذٍ في الناس، ومن ثَم الإقتاع بإدانته، مـادام الحِجَاج في جوهره " عملية استدلال

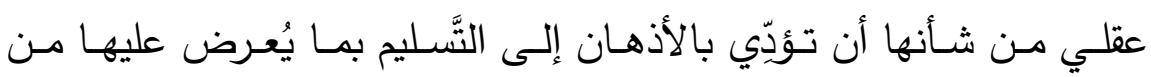
أطروحات أو أن تزيد في درجة ذلك التَّليم (9)").

\section{( نموذج تطبيقي )}

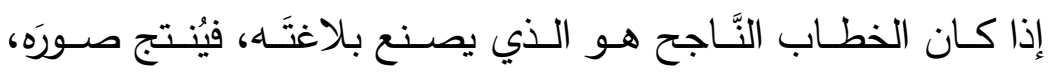
وأساليَهه، وإيقاعَه، بالكيفيَّة التي تحقق غاياته وأهدافه، فإنَّ توظيف الخطاب القضائي للاستعارة بقصد تحقيق التَّأثير والاستمالة اللذَيْن يعدَّان مظهرًا من مظاهر نجاحه؛ لِمَا تمتلكه الاستعارة من قدرة هائلة على تغيير زاوية الرُّؤيـة، واستتارة إرادة الفعل في نفوس المخـاطَبين، وحملهم على تبني وجهـة نظر

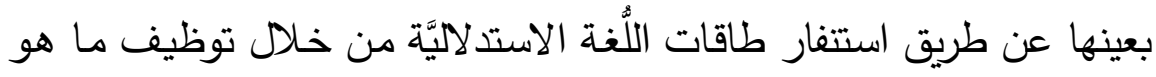

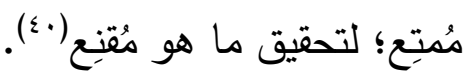
وسـوف نعرض - هنـاـ- لكيفيَّة استثمار النِيابـة العامَّة لطاقـة التَّخييل الاستعاري في إقناع القضاة بإدانة المتهم، حيث عمدَتْ إلى استخدام بعض

مب-سيمينو، إيلينا: الاستعارة في الخطـاب، ترجمـة: عمـاد عبد اللطيف، وخالد

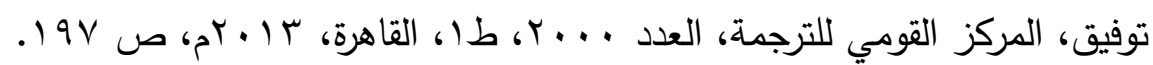
q ب- المبخوت، شكري: نظرية الحجاج في اللغة، ضمن أهم نظريات الحجاج في لتردي التقاليد الغربية من أرسطو إلى اليوم، إشراف حمادي صمود، كلية الآداب، منونة،

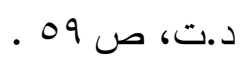

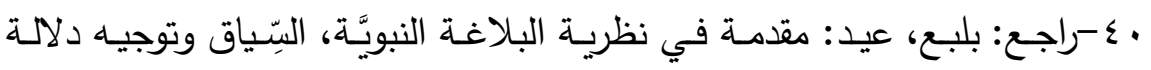

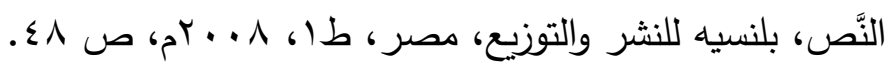




\section{توظيف تقنيات الحِجَاج البلاغي في الخطاب القضائي مقاربة في تحليل الخطاب الجاد}

الاستعارات المفاهيميَّة الدالة على الفوضى وعدم الاكتراث؛ من أجل تحديد الإطـار المفـاهيمي للقضـية، ومـن ثَم تشكيل صـورة ذهنيَّة لشــص وفكر المتهم لدى المخاطَبين (1ء).

\section{مرافعة النّيَابة العامَّة}

\section{في قضية ديوان وطنيتي للشيخ علي الغاياتي • 91 ام(ثء)}

أَصَدَر الثَّيخ علي الغاياتي ديوانه الثَعري الأول (وطنيتي)، وقَدَّمَ لهه

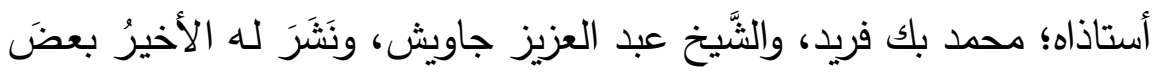
قصـائده في جريدة (اللواء) التي كان يرأس تحريرها. وقد رأتِ الحكومـة أنَّ الديوان يحضُّ على كراهيتها والعيبَ في ذاتِ وَلِي الأمر ، كما رأتُ اشتمالَه على جرائم يعاقب عليها القانون؛ فقامتُ بضبط الديوان، وأحالت الغاياتي،

إ- لن نعرض لتحليل مرافعة الدفاع؛ لخلوها من توظيف الصور البيانية، حيث

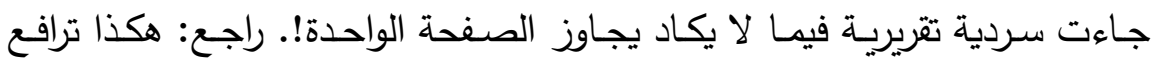

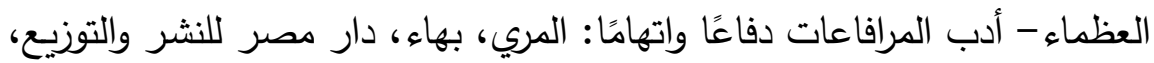

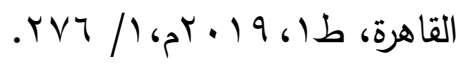
r ب - الثَّيخ علي الغاياتي: عالم دين مصري من جيل مصطفى كامل، ومحمد

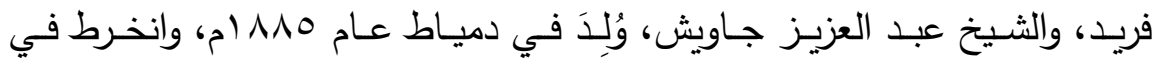

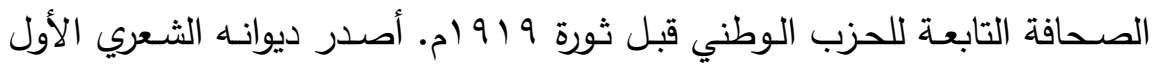
(وطنيتي)، وقَدَّمَ له أستاذاه؛ محمد بك فريد، والثَّيخ عبد العزيز جاويش الذي نَشَرَ

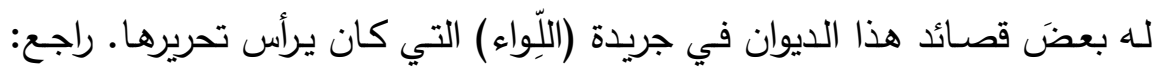
هكذا ترافع العظماء، / / 


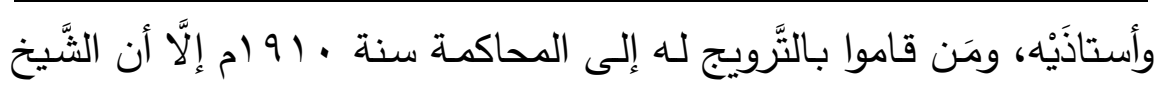

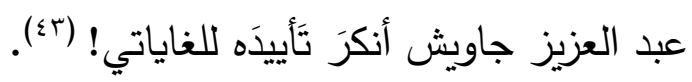
فقـام محمَّد توفيـق نسيم رئسيس النّيابـة في محكمـة الاسـتئناف العليـا

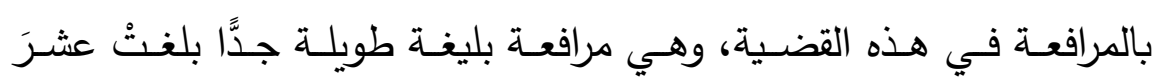

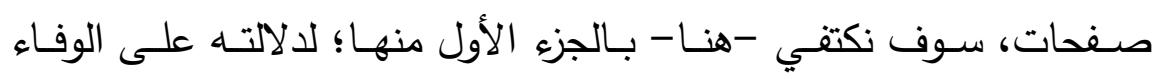
بموضوع هذا المبحث، وهو الحِجَاج بالاستعارة، جاء فيها: " وإِنّي لمحدثكم

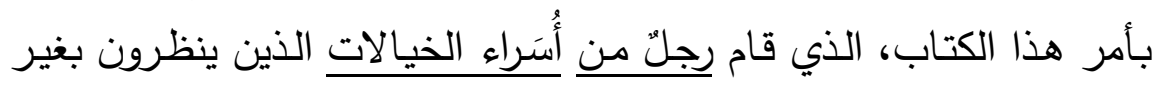
رَويَّة، ويحكمون بغير عقل، وأخذ لنفسـه حظَّهـا مـن لذَّة استباحة الجرائم وتعظيم الجناة، ومن سوء التَّهجم على أسمى مقام في البلاد والتَّجريح على ونى

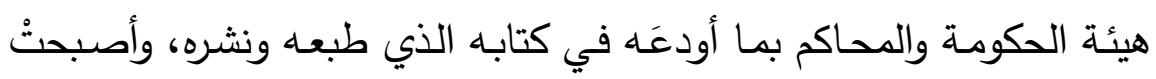

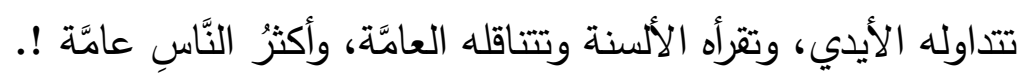
وضـحَ هذا الثـاعر المفتون ذلك الكتاب، ووَسَمَهَه بـ " وطنيتي" !!، فـلا

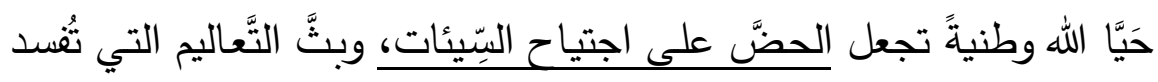

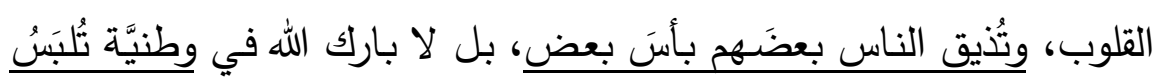

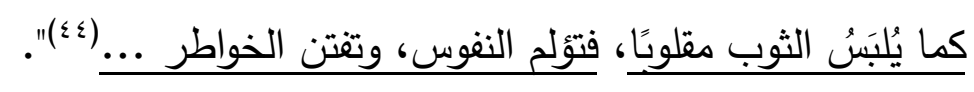
- مقاربة في تحليل خطاب النيابة : كرَّسَتِ النّيابة في هذه الفقرة من خطابها لسلبية اللَّيوان وخطورته على

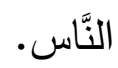

זع- راجع: المصدر السابق: / / ه7ץ.

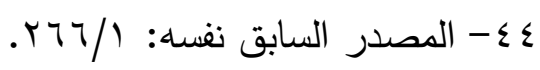


* فصساحبُه:

- رَجـلُ مـن أُسَـراء الخيـالات، الذين ينظـرون بغير رَويَّة، ويحكمون بغيـر

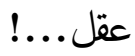
- أخذ لنفسه حظها من لذة استباحة الجرائم وتعظيم الجناة...؛ : ووطنيتّه - تجعل الحضَّ على اجتياح السِيّئات.... - وبنَّ التَّعاليم التي تُقَسد القلوب، وتُّيق الناس بعضَهم بأسَ بعض. - وطنية تُلبَسُ كما يُلبَسُ الثُب مقلوبًا !

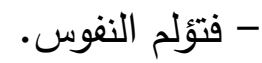

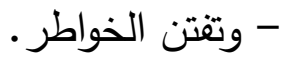
عمدت النّيّابة العامَّة في هذه الفقرة من المرافعة إلى حثد مجموعة من الاسـتعارات المفاهيميَّة التي يسـاند بعضـها بعضًَــا مـن أجـل التَّأثير على القضـاة، ودفعهم نــو فعـل بعينـه، وهـو الاقتتـاع بإدانـة المـتهم، ومـن هـذه الاستعارات قولها :

- " رَجلُ من أُسَراء الخيالات": انبنى التَّصور الاستعاري في هذه الاستعارة

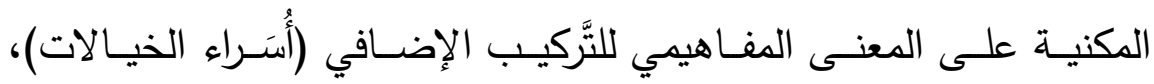
الثاخص إلى المبالغة في إدانة المتهم عن طريق تصويره في صورة الأسير الذي وقع في أسر الخيالات والأوهام التي جعلته يذهل عن واقعه وحاضر أمته؛ فيشط كل هذا الشطط، ومن ثَم جاء الارتباط في الاستعارة بين مجال الانطـلاق (رَجـلُّ)، ومجـال الوصــول (مسن أُسَـراء الخيـالات) حـاملً معـهـ 
تمثيلاتٍ ذهنيَّة سلبيَّة عن شخص المتهم (الغاياتي) الذي استسلحَ لأوهامـهـ

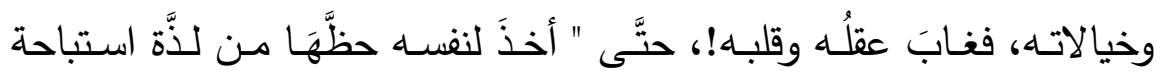
الجرائم وتعظيم الجُناة"!، وقد قدَّمت الاستعارة دليلً على استباحة (الغاياتي) (الجرائم، وتعظيم الجُناه)، بوصفه رجلًَ (من أُسراء الخيالات)، وهو ما يُقدِّم تفسيرًا لكل هذه الفوضى التي أثارها ديوانـه في الناس حتَّى صـار حَربًا على الوطنية الحقَّة.

فوطنيتُه " وطنيَّة...، تُنيقُ الناسَ بعضَهم بأسَ بعض!"، وتلك استعارة

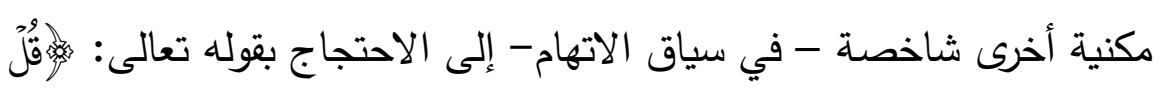

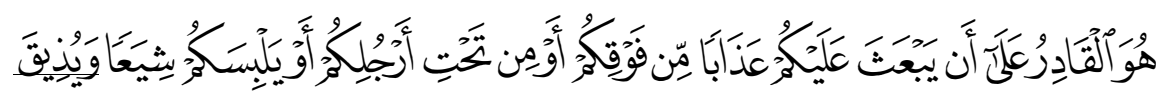

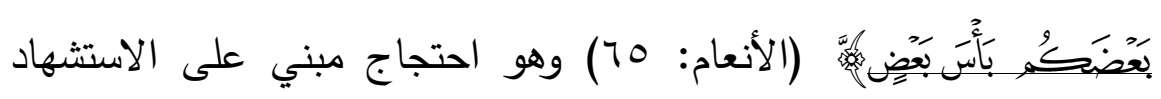
بالحجَّة النقليَّة في بنية الخطاب؛ بقصد الاستدلال على بشاعة أفكار الذّيوان التي يدل عليها الفعل التَّكثري للاستعارة المكنية (تُذيق) المُجيِّد لبشاعة أفكار الديوان، والفتنة التي أحدثها في جموع الناس يومئذٍ بما حواه من حضٍ على الكراهية، والانتقام!. وهو ما جسَّدته الاستعارة بوضوح عن طريق تمثيل وتلوين المجرَّد (الوطنيَّة) بملامح المادي (الطعام / الشراب) من خلال البؤرة

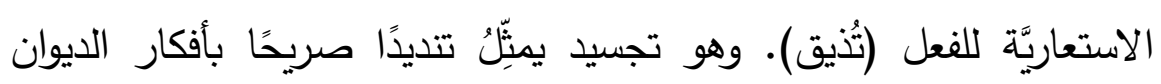

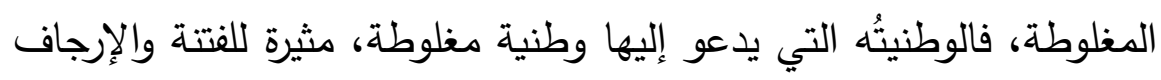
في الناس.

ولا تزال النّيابة تعدد إلى التَّقَي في الدليل عن طريق استخدام سلطة التَّخييل المجازي، المستندة بدورها إلى القياس والتَّثيل في كثف الحقيقة، وتبشيع الجريمة؛ حيث لجأت أيضًا إلى الاستعارة المكنية في قولها: "وطنيَّةُ 
تُلبَسُ..."، لتصوير الوطنية بالثوب الذي يُلبس، وهو تصوير وإنْ كان يحمل

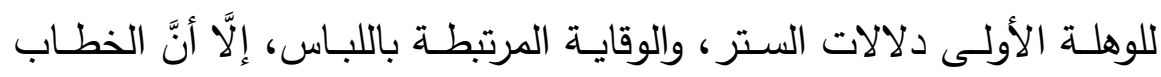

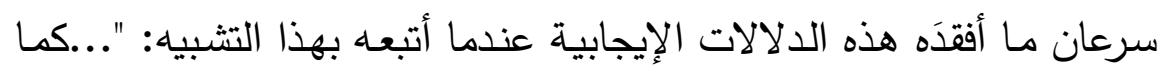

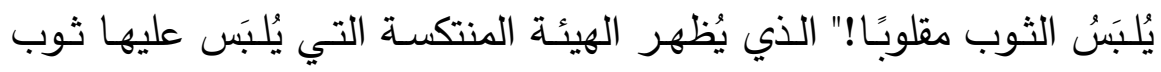
الوطنية، إنَّها هيئة مخالفة لما تعارفه الناس وألفوه، وهذا استدلال بياني يبرزُ الاختلافت إلى الواجهة بين وطنيَتْن متتاقضتين: وطنية حقة، ووطنية الديوان المنتكسة.

زاوجت النّيابـة -إذن - في الاستعارة والتشببيه السَّـابقين بين المعنى الجمالي القائم على التَّثيل الممتع، والمعنى الوظيفي القائم على الاستدلال

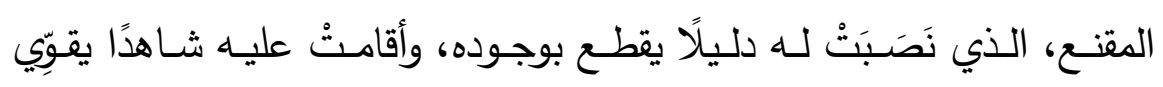

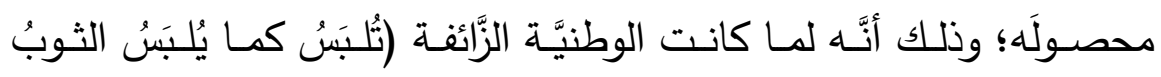
مقلوبًا)، كان من الطبيعي أن يكون لها كل هذا الانتكاس المثير للسخرية والازدراء جميعًا.

وتحساول النيابـة الوقوف على الأسـباب التي دعـت (الغايـاتي) إلى تضمين ديوانه كل هذا الشَّطط، فلا يسعفها في ذلك إلَّا الوظيفة الحِجَاجيَّة للاستعارة، حيث ذهبتُ إلى أن السَّبب في ارتكاب مثل هذا الثَّطط، هو: "جلوس الكتَّاب وراء كلامهم، فيطير بهم خيالهح ويرسلون أقلامهم، فيحملون على الرّجال، ويرمون البعضَ بالمروق، والبعض بالسُّو، وهم يظنون أنَّهم يُحسنون صُنَعا (؛)؛")"

0ـ- المصدر السَّابق: rVY/I. 
أدَّت الاستعارة الاسميَّة: " جلوس الكتَّاب وراء كلامهم" وظيفةً استدلاليَّة إقناعيَّة في الخطاب؛ فهي مسوقةٌ للاستدلال على عدم اكتراث (الغاياتي) لما يقول، وهو مـا يؤكِدِه مجالُها التَّداولي الثَّاخص إلى حمل القضــاة على أن

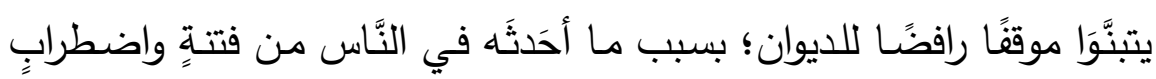
بالغَيْن.

وإذا كانت الكلمات لا يمكنها أن ترسم إلَّا إذا جعلتِ الأشياء في حالة

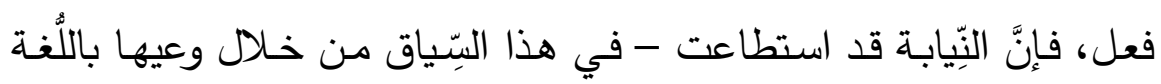
التَّصويريَّة- أن تجعل الكلمات في حالة فعل، على نحو ما يُظهره التصوير الاستعاري الذي يرسم صورة مشهدية (للغاياتي)، فهو ممَّن: " يجلسون وراءَ كلامهم"، وهو تصوير يُستدل بـه على جُبن هذا الصنف من الكتَّاب الذين يُّن

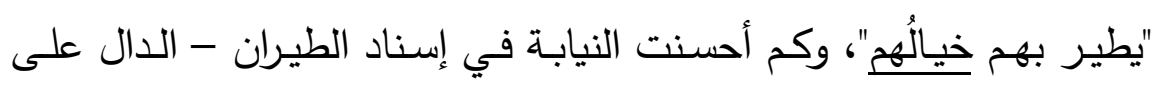

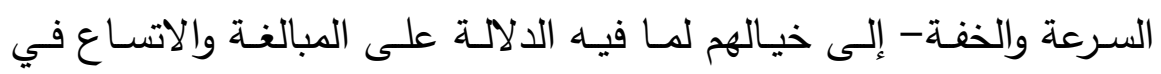

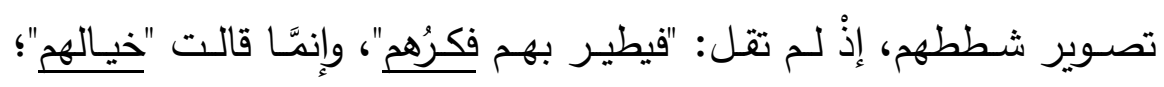

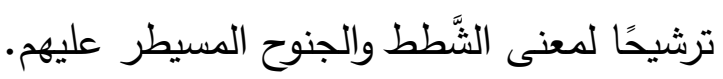
هذا، فضـلًَ عن تعزيز المعني المحَاجِج لهاتين الاستعارتين بتتاص

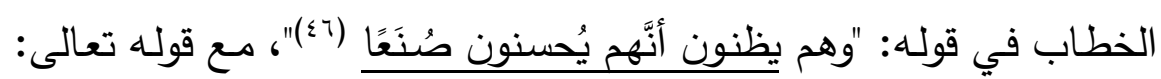
: الكهف ع • ()، وهو تتـاصُ داعم ومسـاند للدلالات السلبية التي جسَّدها التصـوير الاستعاري السابق.

$$
\text { Tצ- المصدر السَّابق: YVY/I. }
$$


إنَّ اختيـار النيابـة لهـذه الاسـتعارات دون غيرهـا في سـياق الاتهام، يعكس ثقتَها في كونها أبلغ في الحِجَاج وأقدر على تجسيد المعنى والاستدلال عليه، كما يعكس وعيها بكيفيَّة تأطير الخطاب (موضوع) القضية، ووضـع تصـورات بعينها في الصَّدارة، بحيث يمكنُها استدعاء انفعالات، وتقييمات بعينها للديوان وصاحبه، ومن ثَمَ لم تَسقط استعاراتها خارج موضوع الخطاب؛ لَّاء فقد تجاوزت المظهر التَّخيلي الاحتفالي إلى الوظيفة الحِجَاجيَّة المتمثلة في الاستدلال على تجريم فعل (الغاياتي)، ومن ثَ إقناع القضاة بإدانته. وهكذا نجحت النِّيابة في عرض القضية عرضًا حِجاجيَّا مؤثًِّا، اتَّتقتُ فيه مجموعةٌ من الاستعارات الحِجَاجيَّة: ( أُسَراء الخيالات - جلوس الكتَّاب وراء كلامهم - فيطير بهم خيالهم - ويرسلون أقلامهم ...)، التي استمالت المخاطَبين، ودلتهم - دون مغالطة أو تمويهـ من خلاءل تقاعلهم مع معانيها

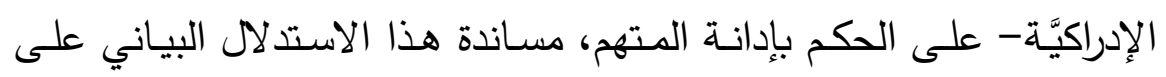
إدانـة المتهم بمجموعـة من التَّراكيب ذات المعـاني السَّلبيَّة، مثل: (ينظرون بغير رويَّة- يحكمون بغير عقل - يحضُ على اجتياح السيئات- - إفساد

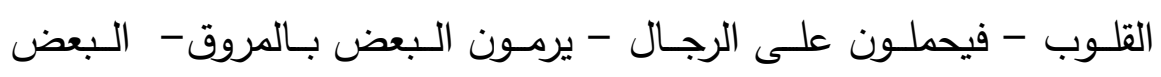
بالسوء...)، الأمر الذي أتاح للقضاة استحضار تفاصيل القضية، والاستدلال على وقائعها، ومن ثَم سهولة تكوين رأي قانوني بشأنها. 


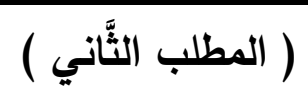

\section{حِجَاجيَّة السُّؤال}

لا يكفي في صناعة الخطاب أن يَعرف المره ما يقول، وإنَّما عليه أن

يعرف كيف يقول("iv)، وهو ما يعني أنَّه على صـانعي الخطاب القضـائي أن

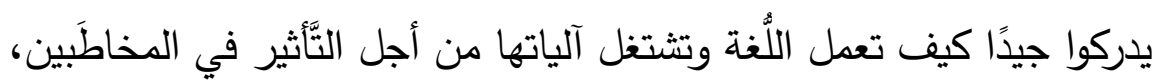
فيسألوا أنفسهم قبل إعداد خطاباتهم:

1- ماذا الذي ينبغي أن نقول؟، أي: لماذا نسأل؟ ( الهدف من السُّؤال). Y- كيف نقول مـا نريــ ؟، أي: كيف نسـأل عمَّا نريد؟؟ ( استراتيجية بنـاء (السُؤال).

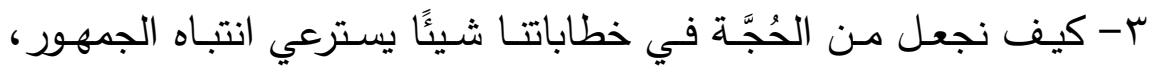
ويستدعي موالاته أو على الأقل تعاطفه ؟ ( استراتيجيات الخطاب في تحقيق أهدافه).

كما ينبغي عليهم أن يفهموا عقلية ووجدان الجمهور / المخاطَبين، فيبنوا خطابـاتهم على النَّــو الذي يلائمهم، وينسـجم مـع فضـاء خطـابهم زمانَا ومكانًا، ويدركوا أنَّ لكلِّ موقف وسائله التَّثَثريَّة والإقناعيَّة التي تناسبه، وأن يتذكروا أنَّ مراعـاة الاعتبارات البلاغيَّة في الخطساب ذات شـأنٍ في تحديد مضـمون الحُجَّة، ومدى تقبـل الجمهـور لهـا؛ لأنَّ " مِفتـاح البلاغـة المـؤثرّة يكمن في تكييف القواعد الأساسية للشكل والأسلوب وفقَ متطلبات الجماهير

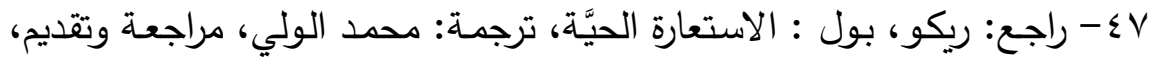

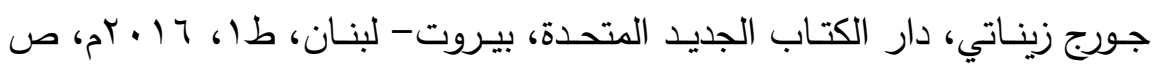
.$\wedge \varepsilon$ 


\section{توظيف تقنيات الحِجَاج البلاغي في الخطاب القضائي مقاربة في تحليل الخطاب الجاد}

والبِّياقات المختلفة(^))"، وهو ما يُعرف في البلاغة العربية بـ "مراعاة مقتضى

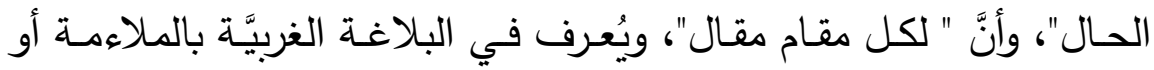

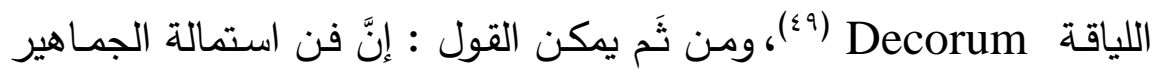
والتَّثَير فيهم لا يحدث في فراغ بلاغي، لا سيَّما إذا كانت البلاغة تستثمر

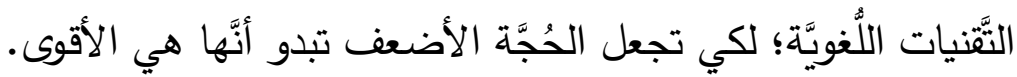
فلـو كان مقصد الخطاب تقريـر الخَصْـم، أو المتهم بالواقعـة المنسوبة

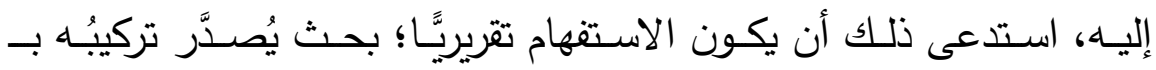

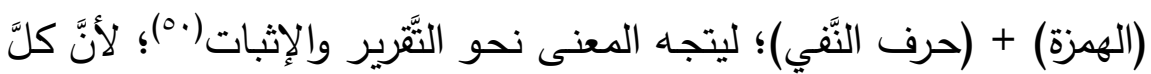

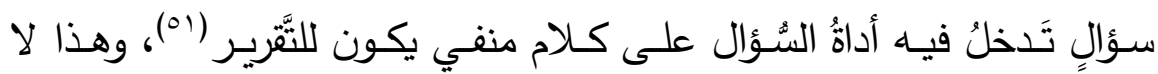

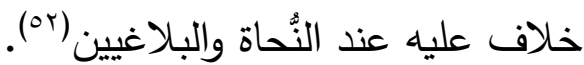

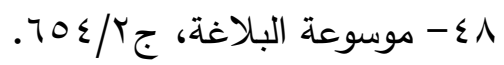

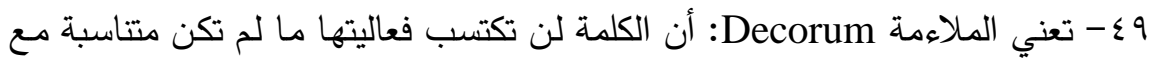

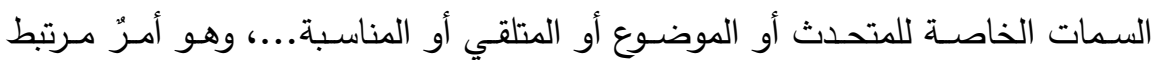
بالخبرة الجمالية، والحدس الفني. ( موسوعة البلاغة / / • (77، وما بعدها ).

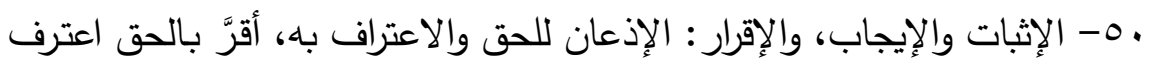

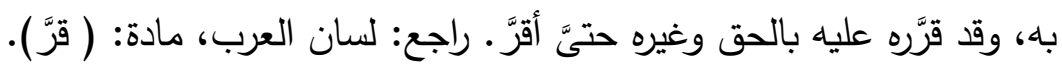

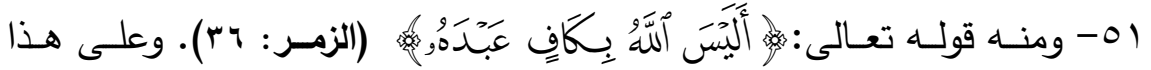
يجب أن نفهَ المعنى في كلِّ "سؤالٍٍ" ورد على هذا النَّطط التَّركيبي. ror-راجـع: الرَّضــي الاسـتراباذي: شـرح كافيـة ابـن الحاجـب، المكتبـة العصـرية،

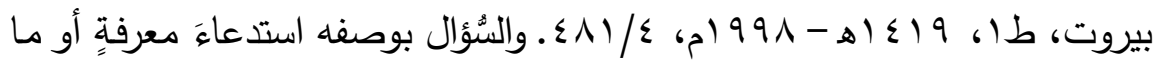

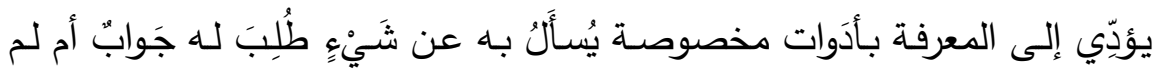

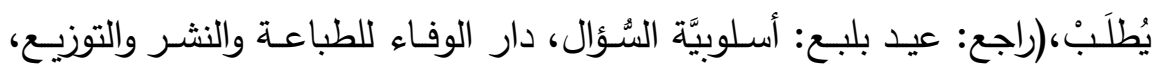

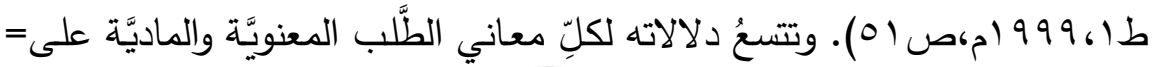


كمـا تُستعمل همـزة الاسـقهام لطلب التَّصـديق، أي: للاسـتفهام عـن حقيقِة نِسبَِِ قولٍ أو فعلٍ أو صفةِ إلى شخص مـا، إذا تليها الفعلُ مباشرة،

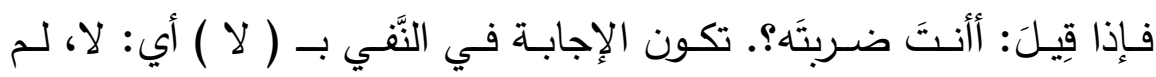
أضربْه. وفي الإثبات بـ (نعم) أي: نعم، ضربتُه.

ويُطلَق على مثل هذا النوع من الأسئلة في الخطاب القضائي أسئلة

إثبات الإدانة، أو أسئلة توجيه التُّهم، كأن تقول النيابة للمتهم، مثلًا : لإنه - حينما حاولتَ الهربَ قاومَك المجني عليه، فطعنتَه. أليس كذلك ؟ تريد النيابـة بمثل هذا السُّؤال تقرير المتهم بارتكاب جريمته، وكأنَّها

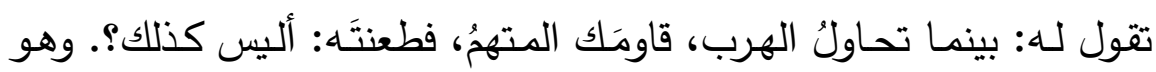
سؤال مبنيٌْ على الخداع، حيث قصدت النّيّابـة دفحَ المتهم إلى سَرد وقائع مقاومـة المجني عليـه لـه؛ لتجعلَه يغفل عن القصــ في تسـيل الاعتراف بطعنـا!. وهو مـا يعني أنَّ حِجَاجية السُّؤال لا تكمن في الإجابـة التي قد ينشدها، بقدر ما تكمن في الدلالة التي تتوجه إليها بِنْيتُه وسياقُه. إنَّ مثل هـذه الأســلة والاعتبـارات وثيقـة الصـلة بتقديم الأدلـة القانونيَّة

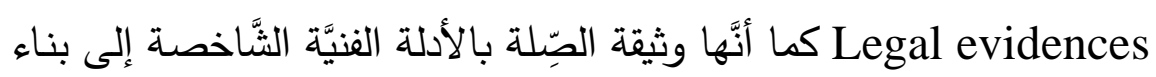
خطاب حِجَاجِي ناجح.

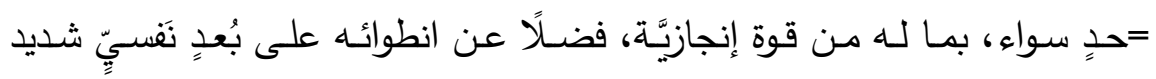

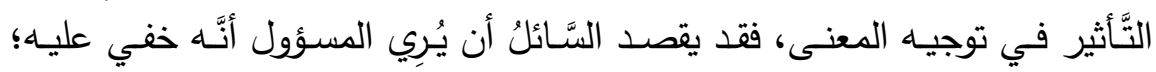

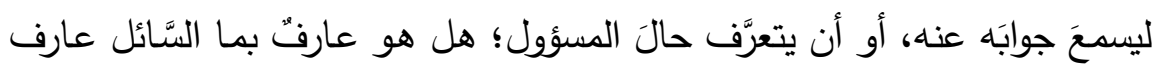

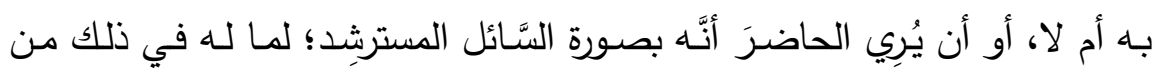
الغرض. (راجع: الخصـائص: ابن جني، أبو الفتح عثـان، تحقيق:محمد علي لـي

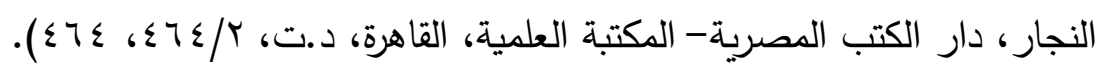


والمتمرسـون بالخطـابَيْن القضــائي والقـانوني على درايـة بطـرق بنـاء

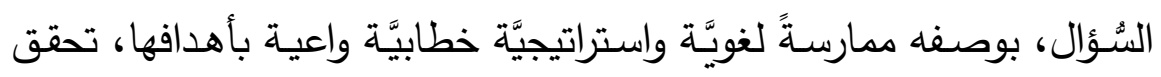
فعلَ المفاجأة الذي يكسر جمود التَّقعُ، فهم مدركون أنَّ صيغة السُّؤال مهمة

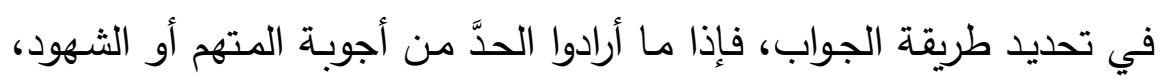
لجأوا إلى الأسئلة القسريَّة، أو الإكراهيَّة التي تتطلب إجابـة واحدة بصسيغة

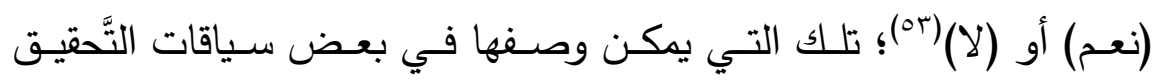

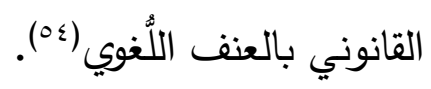

وتعتمد استجوابات الثُّرطة، والنيابة، والقضـاة عـادةً على استراتيجية

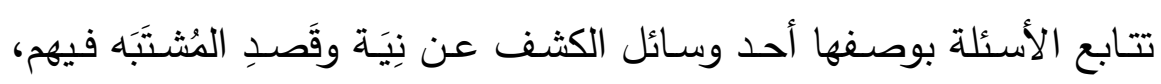
والكثف عن مدى تخبط المتهم أو المشتبه بهم، أو الثهود(00). هذا، فضـلًا عن قدرة الدِّفاع في التَّتَكيك في الجريمـة المنسوبة إلى موكله عن طريق طرح أسئلة على الادِّعاء تتعلق بالتَّعريف القانوني للجريمة

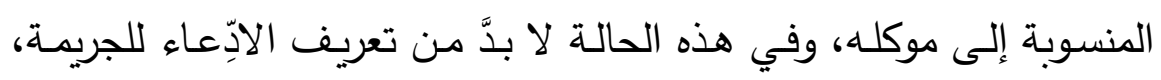
وإثبات التَّعريف، ثم مقارنته بالفعل الذي المنسوب إلى المتهم، وهو ما يعطي فرصة للدفاع لمهاجمة كلام الإِّعاء ودوافعه.

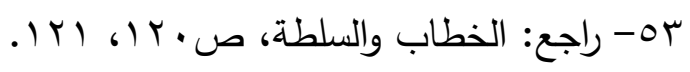

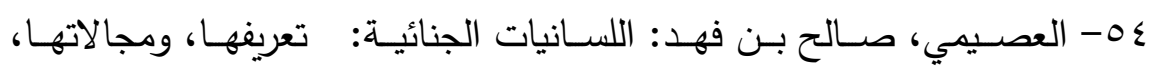

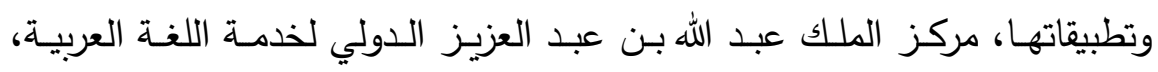

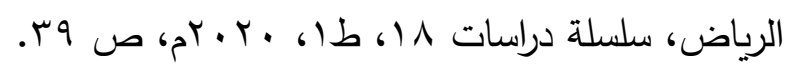

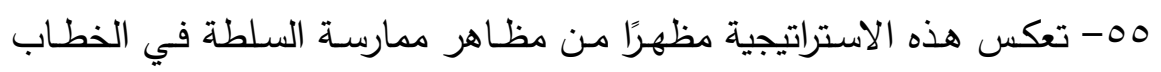

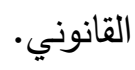


كما يمكن لاستراتيجية السُؤال في الخطابَيْن القانوني والقضائي أن تمثِّلَ نقطـة تحول في القضسية المنظورة أمـام القضـاء أو جهات التَّحقيق، إذا مـا

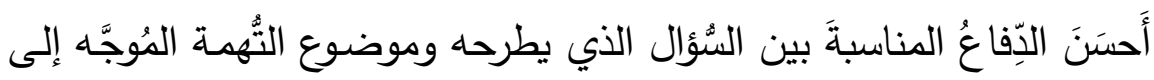

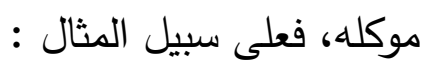

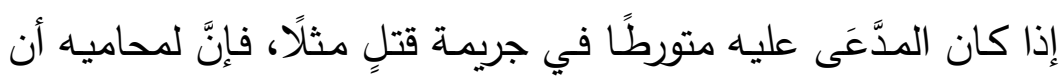
يحتجّ بالسُؤال عن كيفيَّة الوفاة: - هل وقعتُ نتيجة انتحار؟ - أم وقعتُ نتيجة مشاجرة؟ - أم وقعتُ نتيجة تَعمُّد؟ وإذا كان القتل مع سبق الإصرار، فيكون السُؤال عن دوافعه : - مـا الذي دفع المتهم إلى ارتكاب جريمته (دوافع ارتكاب الجريمـة)؟؛ لأنَّ

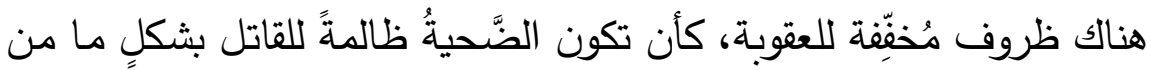

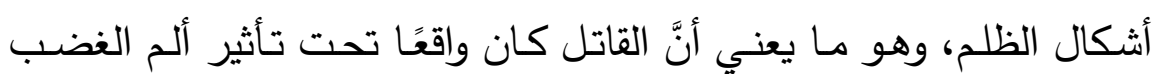
بوصفه محرّكًا للنفس بَعيدًا عن طبيعتها ومُخرجًا لها عن طورها، ومستصحبًا للذة الانتقام التي تدفعه إلى الاعتداء، أو القتل. - هل كان الجـاني واقعًا تحت تأثير ضـغوط نفيَّة، أو مرض عصبي أو عقلي معين؟

ومن ثَّم فلا يجب النظر إلى السُّؤال بوصفه مجردَ فعل لغوي يُنتجها المتكِلم فحسب وإنَّمـا يجب النظر إليها بوصفه أحد استراتيجيات الخطـاب؛ 
للسيطرة على مجريات الأحداث، بل والسَّيطرة على ذهن المخاطَب، وتسيير الخطاب الوجهة التي يريدها المُرسِل لا حسب ما يريده الآخرون(بهاب.

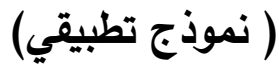

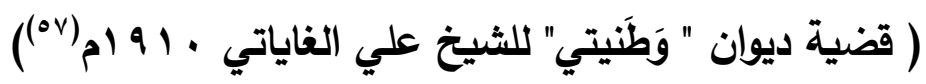

سـوف نعتمـد في هذا النمـوذج التَّطبيقي أيضًا على قضـية ديـوان

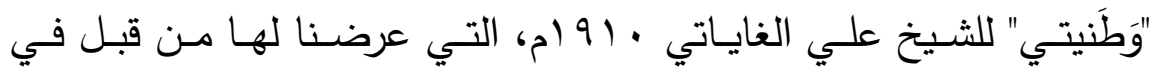
الحِجَاج بالاستعارة؛ لنرى كيف نوَّعت النيابـة في استخدام تقنيات الحِجَاج البلاغي، وفقًا لما استدعته استراتيجيات الخطاب؛ بقصد تحقيق أكبر قدر من الاستدلال على إدانة المتهم.

قالت النّيّابة العامَّة في مرافعتها في قضية (ديوان وطنيتي) المتهم فيها الثيخ الغاياتي، ومحمد بك فريد، والثَّيخ عبد العزيز جاويش، على سبيل

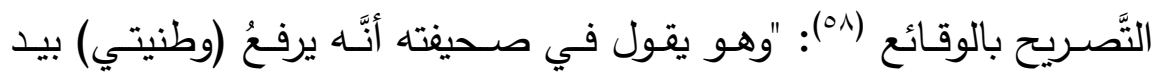
الإخلاص إلى إِمَامَي الوطنيَّة، وقَائدَي زِمَام الحركة الحاضرة، رئيس الحزب الوطني محمد بك فريد، والثَّيخ عبد العزيز جاويش، يرفحُ لهما ويهديهما الكتاب الذي هو عنوان شعور نفسه، وقد تعهدَاه وأمدَّاه.

1هـراجـع: الثـهري، ظـافر : اسـتراتيجيات الخطـاب، مقاربـة لغويـة، دار الكتـاب

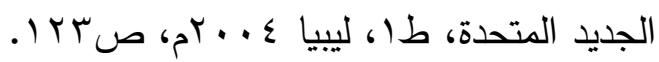

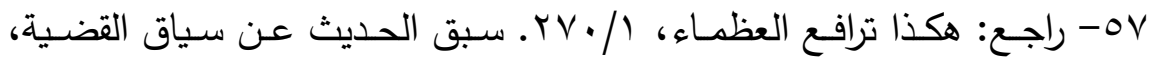

$$
\text { راجع: ص ص سا. }
$$

10ـيُعدُ التصريح بالوقائع ومواجهة المتهمين بها، أحد استراتيجيات الإقناع في الخطابين القانوني والقضائي. 
- أليس هذا اعتراف صَربح بانتمائهم وتعاونهم على وضع الكتاب المذكور؟ - ألـيس أقوى في الاحتجـاج مـن عبـارات ذات الجـاني التي اطلّع عليها المتهم...(09)

ومن العجيب أن يُنكرَ الثَّيخ عبد العزيز جاويش المقدمةَ التي قدَّمَ بها لديوان الغاياتي، تلك التي قال فيها: " ومَنْ شَاءَ أن يرى نموذجًا من الثَعر

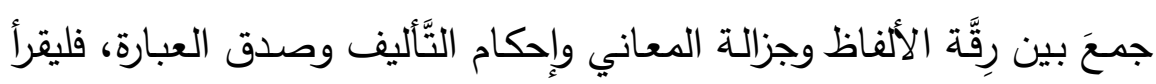

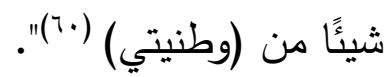

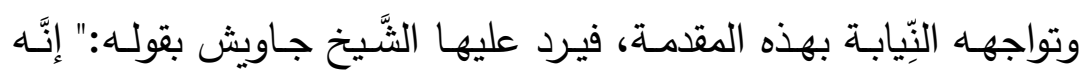
محضُ افتراء وكذب، افتراه الغاياتي لغرضٍ في نغسه (اי)"ا. فتسأله النِّيابة العامَّة بقولها : - أَبَيَكَكَ وبينَهه عداوةٌ تحملُه على إسناد هذا الأمر إليك؟؟ فيُجيب: كلا، ولا علم لي بالسَّبب الذي دفعَه إلى قول ذلك. - أليس هو الغاياتي المُصحِّح بالعلم أخيرًا ؟ - أليس هو الكاتب تلك القصائد في اللّواء قديمًا ؟ - أليس هو المُهدي إليك كتابه حديثًا ؟ - ألـيس هـو المُثنـي عليك، والمعترف بأسـتاذيتك لـه في طـول الكتـاب وعرضه(Tr)

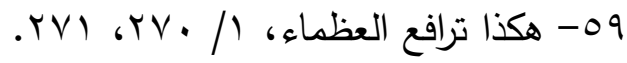

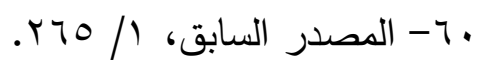

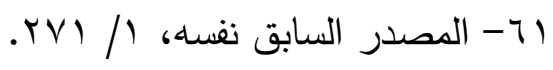


تبدو استراتيجيَّة فِخَاخ الأسئلة التَّزَريريَّة(بآ) واضحًا في مرافعـة النيابة، تلك التي قَصَدَتْ من ورائها تقريرَ الثَّيخ جاويش باشتراكه في التَّرويج لديوان (وطنيتي) للغاياتي، ومن ثَم إثبات اشتراكه في التُّهم الموجهة إلى الغاياتي. حيث استخدمت في مرافعتها الاستفهام التَّرِيري ستَ مراتٍ: منها أربع مرات

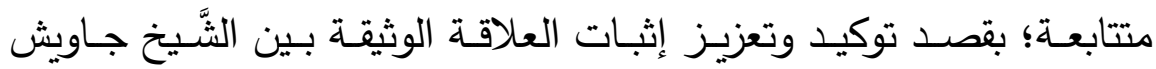

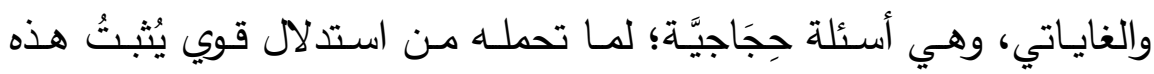
العلاقة الوطيدة بين الرَّجلين؛ فقد أثنَى الثَّيخ جاويش بالفعل على (الغاياتي) في مقدمته للديوان بقوله: " إنَّه المُصحِّح بالعلم أخيرًا ". فجاء السُّؤال منطلقًا من هذا التَّرَظظ على هذا النَّحو: - أليس هو الغاياتي المُصَحِّح بالعلم أخيرًا ؟. والحِجَاجُ في هذا السُّؤال قائمُ على احتواء بِنية السُّؤال على مسلمة لدى طرفي الخطاب: المُرسِل (النّيابة)، والمُرسَل إليه (الثَّيخ جاويش)، وهي ثناء

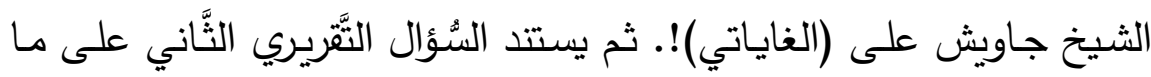

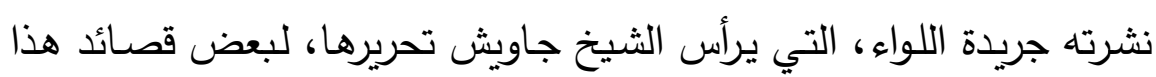

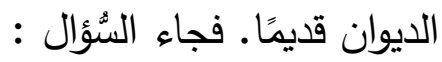

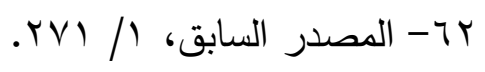

باج- قد يلجأ الخطاب القانوني في بعض الأحيان إلى استخدام استراتيجية السُؤال بقصد تقريـر شـخص مـا بفعلٍ أو قولٍ صـدرَ منـه، وذلك بإنثـاء سـؤال مصدَّر

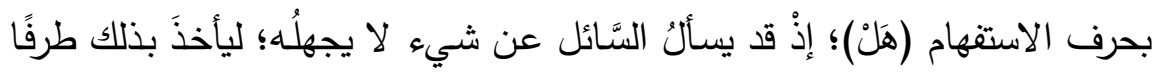

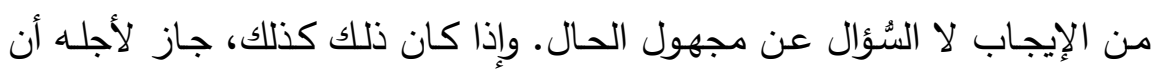
يجرَّد في بعض الأحوال ذلك الحرف لصريح ذلك المعنى. فمِن هنا جَازَ أن تقعَ لأَ

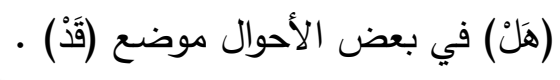


- أليس هو الكاتب تلك القصائد في اللّواء قديمًا ؟ ثم تقرُرُ النّيابـة حقيقـةَ إهداء الغايـاتي ديوانـه للشيخ جـاويش في هذا : السئؤَال : n - أليس هو المُهدي إليك كتابَه حديثًا ؟ وقد نجحتِ النّيّابة في الاستدلال على استحكام العلاقة بين الرَّجلين عن طريـق توسـيع الفضــاء الزَّمنى لهـذه العلاقـة في قولهـا: (... قديمًا -... حديثًا)!

وتُدللُ النيابة في النَّهاية على استحكام العلاقة بين الرَّجلين بما وَرَدَ من ثَناءٍ وافرٍ من قِبَل (الغاياتي) في مقدمة ديوانه على أستاذه الثَّيخ عبد العزيز جاويش، فجاء سؤالها على هذا النَّحو الذي يحمل قوة الفعل الإنجازي: - ألـيس هـو المُثنبـي عليك، والمُعترِف بأسـتاذيتك لـه فـي طـول الكتاب وعرضهـ

أرادت النّيابة -إذن - من خلال تقنية السُّؤال الحِجَاجي، المتمثلة في كلِ

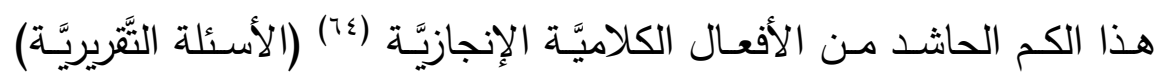
المدعومـة بالأدلة أن تدفع المتهم إلى الإقرار بما يُعرَض عليه، فضـلًا عن التن إقنـاع القضـاة، بمـا تعتقده مـن ضـلوع الثـيخ جـاويش في التَّرويج لقصـائد الغاياتي قديمًا، ولديوانه حديثًا، ومن ثَم الإقرار بإدانته.

ع ا- إنَّ القول بأن أحد أجزاء النَّص يمثل فعلًا من أفعال الكلام، يعني أنه يحدد

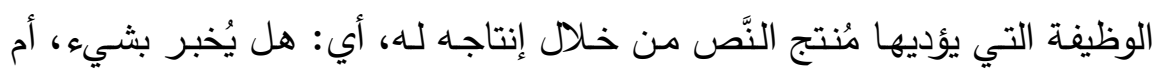

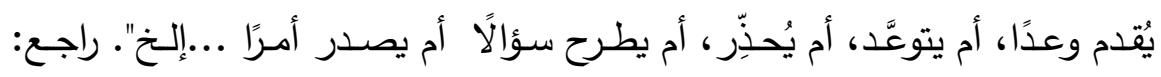

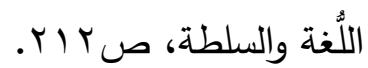


هذا، وقد أسهم التَّكيب اللُّغوي لأسلوب السُؤال في تحقيق مضمونه

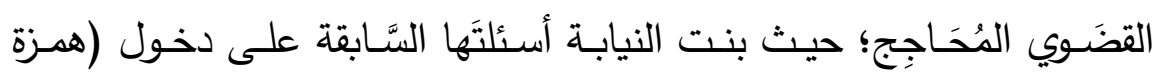
الاستفهام) على الكـلام المنفي المصدَّر بـ (ليس)؛ لإنشـاء سؤال تقريـري،

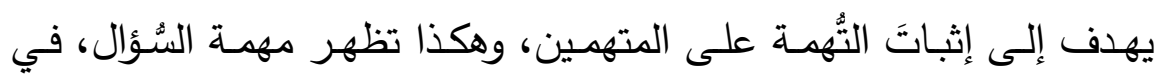
البّيّاق القانوني، بوصفه فن الإثبات في سياقات كثيرة.

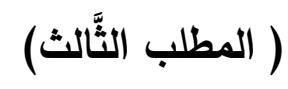
العِجَاج الإليقاعي

إذا كان كلٌّ خطاب يسعى إلى تحقيق أهدافه التي خطَّطَ له عن طريق

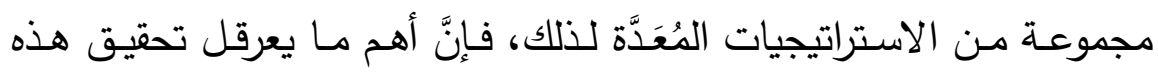
الأهداف هو سلبية المتلقي، تلك التي يلجأ صـانعو الخطاب إلى مواجهتها عن طريق توظيف الإيقاع The rhythm في أحيان كثيرة، بوصفه أحد مظاهر الحضـور الجمالي المقاوِم لهذه المَّلبية، ليس على مستوى المعنى فحسب، بـل على مستوى الصَّوت الذي ينفضُ عن الأذان أغبار الخمول

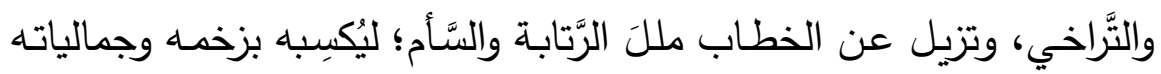

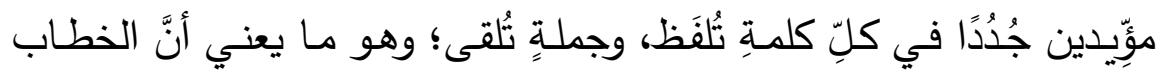
الجيد ينبغي أن يتجاوز في معماره مجردَ الاكتفاء بالإفهام والإقناع، الذي لئي

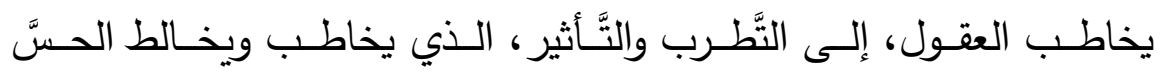

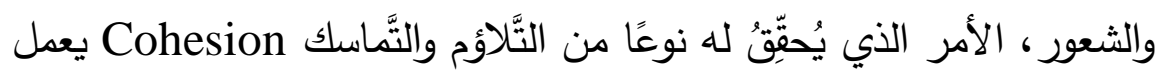
لصالح أهداف الخطاب.

ويشكل الإيقاع في الخطاب بكلِّ عناصره: سجعًا، وجناسًا، وازدواجًا، وتكرارًا، ووزنًا.... عنصرًا جوهريَّا في صناعة الخطاب القضـائي الذي يمثلُ

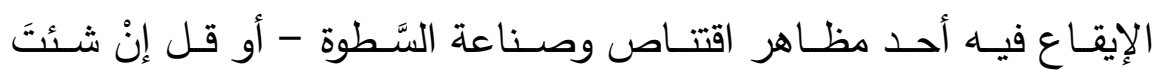


الهيمنـة- بوصفه وسيلة تأثيريَّة مهمـة، تمثل رِهَانًَا لدى الخطيب، يحشـده للتأثير في نفوس مخاطبيه، ويقاوم به الإخفاق في تحقيق أهدافه.

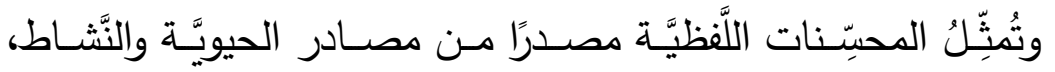

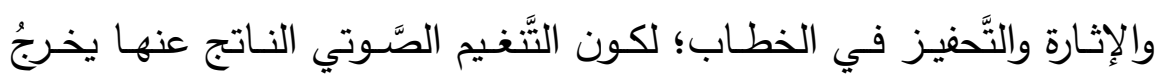

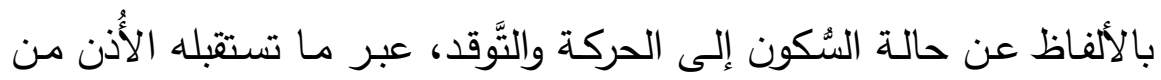
تكوثرٍ نغمي تطرب له النفوس وتلتذ بسماعه الآذان. فالمحامي الذي يترافع - وقد حشد الأدلة المؤكدة لبراءة موكله- مـن دون تتويع في نغمات خطابـه، أو توظيف للإِيقاع، والجَرْس الموسيقي بين

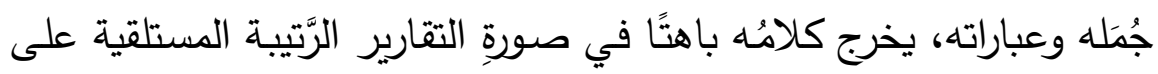

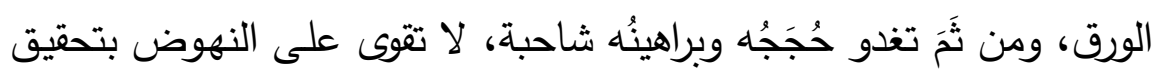
مراده! والسُّؤال الذي يُشيره توظيف الإيقاع في الخطاب، هو:

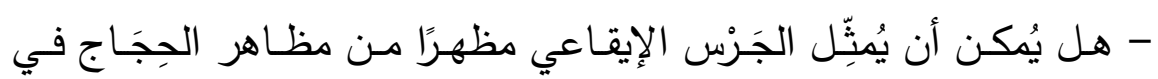
الخطاب ؟

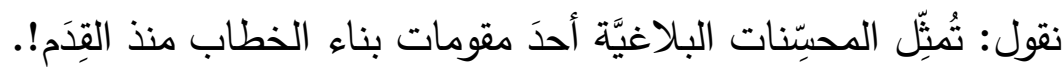
فقد منَّلَ السَّجع -على سبيل المثال - في خطـاب الكهانـة أحسد مظـاهر الحِجَاج في كلامهم(70)، بوصفه إيقاعًا ذا تأثير سحري على المخاطَبين، لـ له

ه7- كان أكثر أهل الجاهلية يتحاكمون إلى الكُهَّان، ويزعمون أنَّ مـع كلِّ واحٍٍ

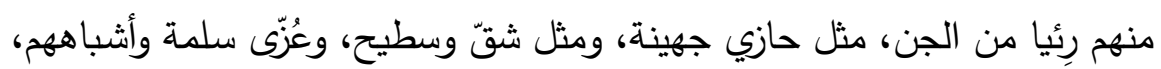

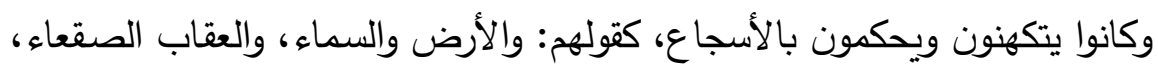




\section{توظيف تقنيات الحِجَاج البلاغي في الخطاب القضائي مقاربة في تحليل الخطاب الجاد}

من السَّطوة، وقوة التأثير فيهم ما لا يُدفَع؛ ولذلك تحفَََّ الإسـلام كثيرًا ضد استخدام مثل هذا التَّحسين اللَّظظي الذي لا يُقِصَدُ به مجرد إقامة الوزن، وإنَّما يُقصَدُ به إبطال الحقوق عن طريق التَّثادق الذي يصل حدَّ الخداع والمغالطة

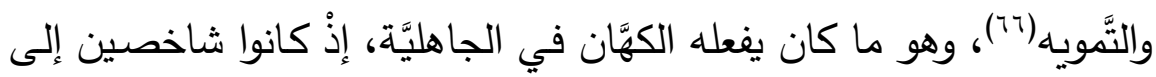
استثمار مثل هذا التَّكثيف والامتلاء الصَّوتي للفظ؛ ليعلو فوق المعنى؛ بقصد

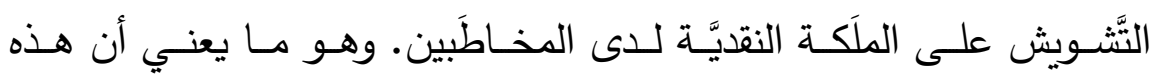

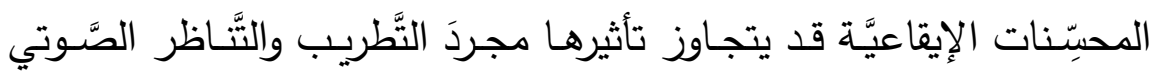
الناتج عن عملية التَّلُّظظ - بوصفها مقولات سميوطيقيَّة- إلى إحداث تأثيرات مباشرة تتعلَّق بالتأثير على قناعات وأفكار المخاطَبين. إنَّ صـناعةَ الخطـاب الحِجَاجِي النـاجح سـتظلُ بحاجـة - أبـدًا - إلـى استراتيجية الحِجَاج الصَّوتي / الإيقاعي بنفس القدر الذي يحتاج فيه معمارُه إلـى بنـاء وصـناعة الحُجَجِ والبـراهين؛ ليخـرجَ الكـلام عـن حالـة الاسـترخاء والفتـور إلـى حالـة التَّكـوثر الصَّـوتي، الـذي تطلبـهـ الثَّـفاهيَّة، بشـرط عـدم

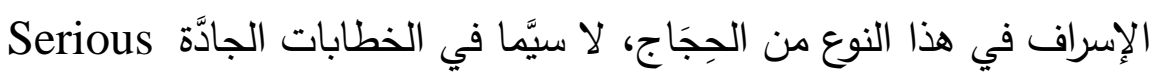
Discourses

واقعـة ببقعاء، لقد نفر المجد بني الثـعراء للمجد والسناء. راجع: البيان والتبيين، $.4 \wedge 9$ 6 $Y \wedge \vee / /$ 47- راجع: البخاري، محمد بن إسماعيل: صحيح البخاري، تحقيق: جماعة من

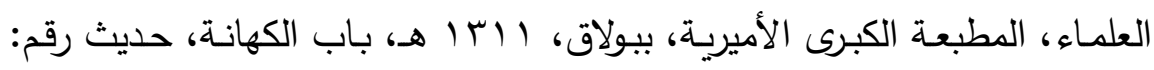
$.110 / 1$ ج 0V0N 
المنشود الذي يسعى الخطاب إلى تكريسه، وهو ما يعني ضـرورة الاحتراز عند التعامل مع الإيقاع الصَّوتي.

وقد لفتَ الإمـام عبد القـاهر الجرجـاني إلى أرشـد سبيل في استخدام السَّجع والتجنيس فقال: " لن تَجد أيمنَ طائرًا، وأحسنَ أولًا وآخرًا، وأهدى إلى إلى

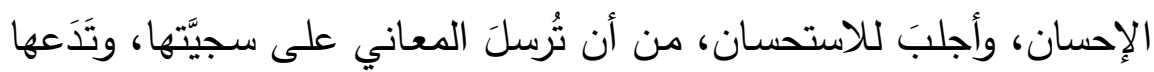

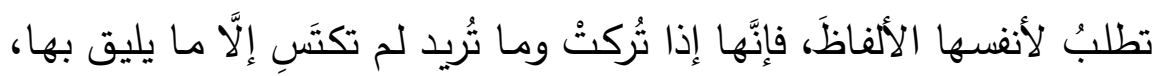

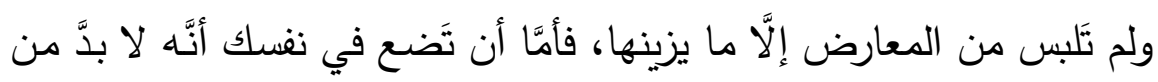

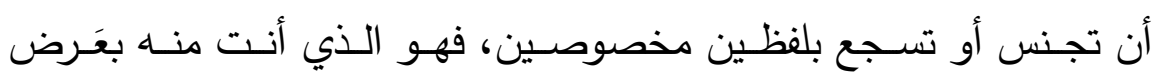

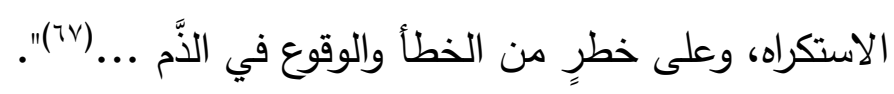
يحذِّر الإمـام عبد القـاهر في هذا النَّص مـن التكلُّف والتعـق في اجتلاب الإيقاع، ويرشدنا إلى أفضل الطرق فيه، وهي " أن تُرسل المعاني على سجيَّتها، وتَدَعها تطلبُ لأنفسها الألفاظ"، فالخطاب الناجح هو الذي إني

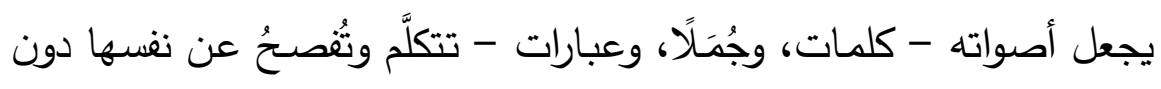
تعسُّف أو إكراه، بحيث يَغدو الحضـور الجمـالي للصَّوت فيه ظـاهرة لافتـة

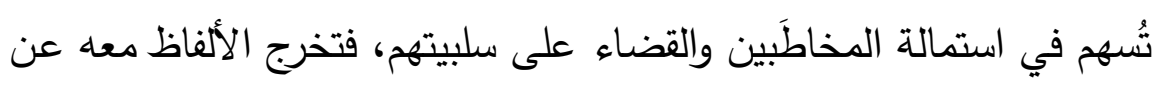
مجرد أداء الوظيفة التَّاصلية إلى أداء وظائف إمتاعيَّة تأثيريَّة، تساند بدورها تحقيق الإقناع من خلال استمالة المخاطَبين والتأثير عليهم • 


\section{توظيف تقنيات الحِجَاج البلاغي في الخطاب القضائي مقاربة في تحليل الخطاب الجاد}

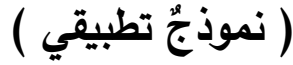

نعرض -هنا- لمرافعة المستشار بهاء المري(^)،ي الجنايتَّنْ رقمي:

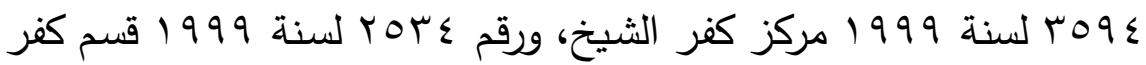
الشيخ؛ لنرى كيف أسهم الإيقاع في تحقيق الإقناع بموضوع المرافعة. يقول: "... نعم، لقد تمرَّغَ الكثيرون في أوحال الجريمة... فطَغَوا وبَغَوا.. واشتدوا في اللَّد.... فلا أخالني أجد مرافعةً أشق على النيابة من أن تترافع في قضية تَلَّلَكَ فيها الإدمانُ من المتهمين.. فددبَّروا .. وفكَّروا.. وقتلوا.. وانتشوا بهذا القتل من أجل ذلك الكيف اللعين!.

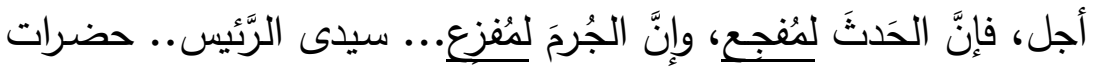

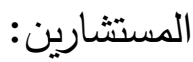

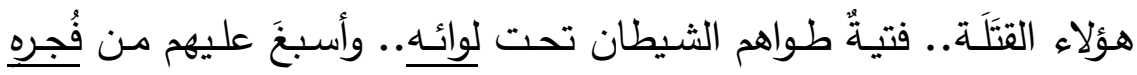
وعناده.. فزيَّنَ لهم الرذيلةُّ.. وقبََّحَ لهم الفضيلةُ، فراحوا في غيهح وطغيانهم يعمهون.. أدمنوا المخدرات..

واستحلوا المُسكِرات.. واستمرءوا البطالةَ والضيالة !. ولكن هَيْهَاتَّ.. هَنْهَاتَ، فهل مثل هؤلاء يَعرفون الرَّحمةِ؟ هل مثل هؤلاء يفقهون عن المروءة والنخوة حديثًا ؟ ويشيع نباُ الحدث، فتولول الزَّوجةُ، تبكي فجيعتَها، عائَلَها، زوجها...

1 1- رئيس محكمة الجنايات، صدرت لله عدة مجموعات قصصية منها: يوميات قاضٍ، فيض الخاطر ، لحظة انهيار، يوميات وكيل نيابة، حكايات قضـائية. من كُتُبه: هكذا ترافع العظماء. 


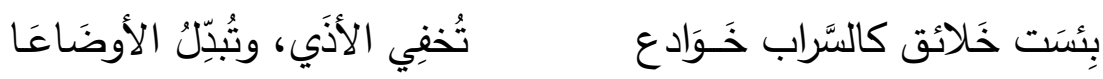

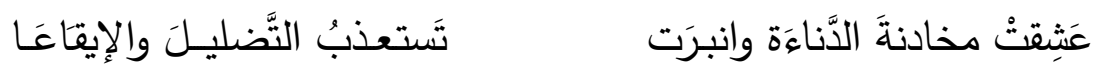
سيدي الرَّئيس، حضرات المستشارين:

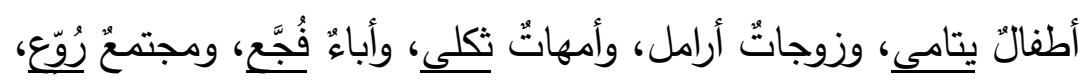

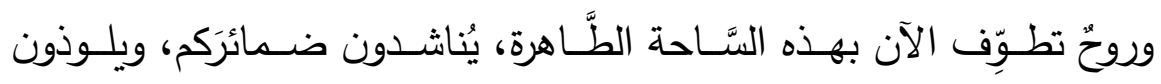
بعدلكم، القِصَاصَ القِصَاصَ (79). - استراتيجية توظيف الإيقاع في المرافعة :

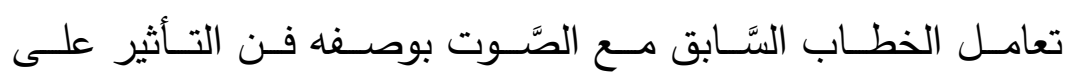
المخاطَبين، حيث وظُّفت الألفاظ، عبر انتزاعها من حال كونها مجرد دلائل على الفكر إلى جعلها استراتيجية تحقق هدفه في استمالة المخاطَبين والتََّثير فيهم. وقد حدث ذلك من عدة جهات، منها: - أولًا: توظيف الإيقاع الصَّوتي : عَدَت المرافعة إلى تحقيق نوع من الإيقاع المكثَّف عن طريق توظيف

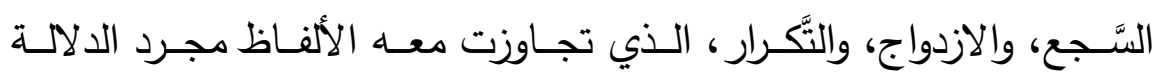

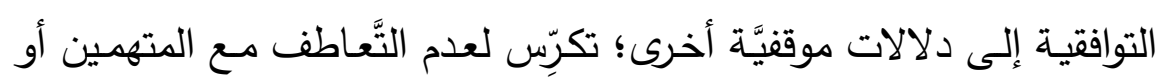
الثَّفقة عليهح من قِبل هيئة المحكمة، وذلك على النحو الأتي:

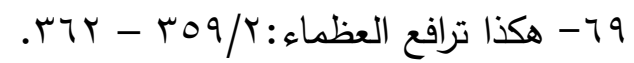




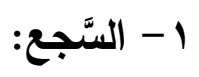

أسهم السَّجع في المرافعة بدور كبير في تحقيق إيقاع صوتي ناصع،

نشأ عن التَّاثل الصَّوتي للحروف في مقاطع الفصول فُV)، كما في قوله : - فإنَّ الحَدَثَ لمُفجعِ، وإِنَّ الجُرجَ لمُفزع. - فزيَّنَ لهم الرذيلةُ.. وقبَّحَ لهم الفضيلتُ. - أدمنوا المخدرات.. واستحلوا المُسكِرات. نلاحظظ أنَّ السَّجع قد مثنَّلَ - في هذا الجزء مـن المرافعـة- الجرْسَ

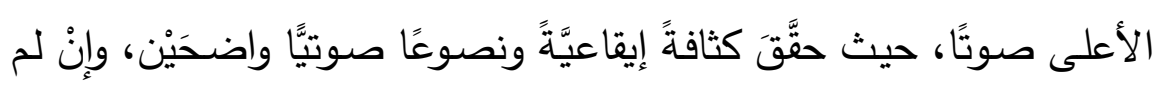

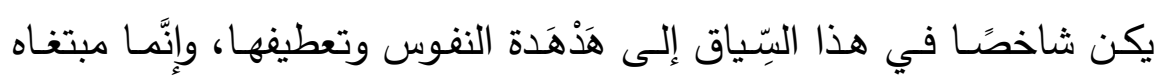
تجريم الفعل لأقصى درجة، وكثف تجرُّ الجُناة من كلِّ خُلُقِ وفضيلة. وقد قامت استراتيجية السَّجع -هنـا- على الترادف، والتَّضـاد: الترادف

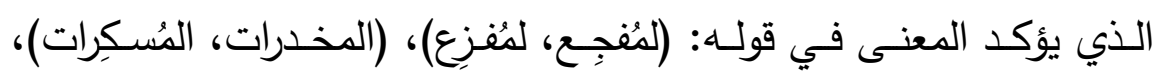
والتَّضاد الذي يبرز الاختلاف إلى الواجهة في قوله: (الرذيلةُ، الفضيلةُ).

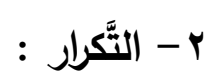

التَّكرار هو إيراد المعنى مُرَدَّدًا(V)، وإنَّما يُفعل ذلك للدلالة على العناية

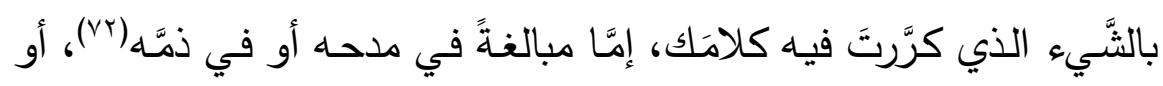

• V-راجـع: الخفـاجي، ابـن سـنان: سِرٌُ الفصـاحة، دار الكتب العلميـة، بيـروت-

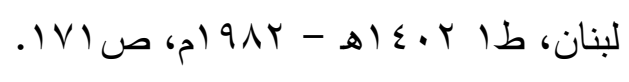

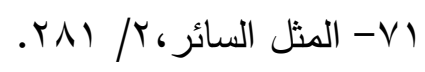
• 
توجيهًا للعناية إليه؛ ليثبتَ ويتقرَّرَ في النفوس. كما يقوم التَّكرار بالإسهام في

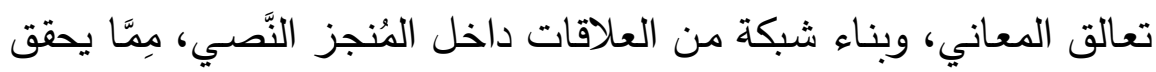

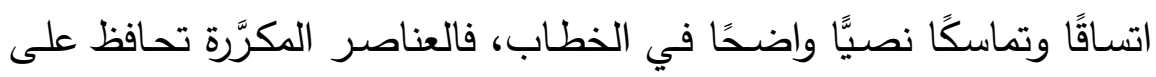

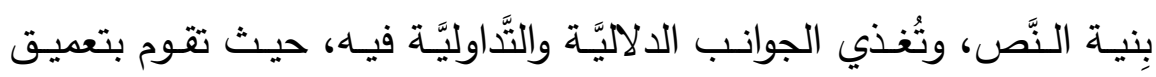
المعنى في ذهن المخاطب عن طريق تكاثر الألفاظ وكثافتها، الأمر الذي يحقق انسجامًا وتماسكًا في معمارية النَّص، ويدعم تأكيد كينونته واستمراريته واطراده(

ونلاحظ في هذه المرافعة قصد النيابة إلى التَّكرار في موضعين، هما:

- ولكن هَيْهَاتَّ.. هَيْهَاتَ، فهل مثثل هؤلاء يعرفون الرَّحمة ؟ هل مثل هؤلاء يفقهون عن المروءة والنخوة حديثًا ؟خن هيأ - القِصَاصَ القِصَاصَ " -

عمل التَّكـرار في هذين الموضـعين على مستوى القيمـة التَّنيميَّة، والدلاليَّة جميعًا؛ حيث أسهم في سياقه النَّصي في خلق نوع من الإيقاعي الحِجَاجي -لا سيَّما إذا وضنعا في الحسبان حنكة المرافعة في اختيار ألفاظ

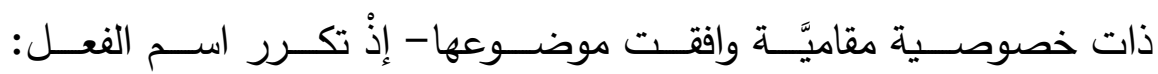
(هَيْهَاتَ...هَيْهَاتَّ) بقصد نفي الرَّحمة عن الجناة والمبالغة في ذِّهَهم، متبوعًا بتكرار الاستقهام الـدال على النَّفي في قولها: ( فهل مثل هؤلاء يعرفون الرحمة؟!)، (هل مثل هؤلاء يفقهون عن المروءة والنخوة حديثًا ؟)، وهو تكرار

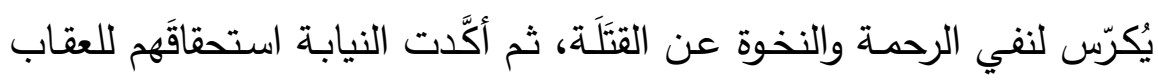

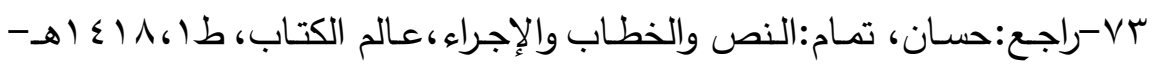

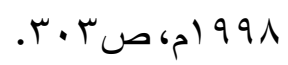




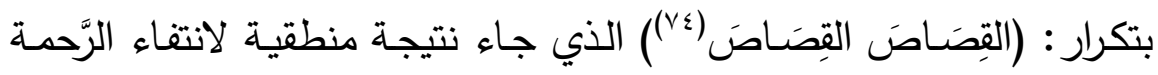
والنخــوة عـنهم، وفي هـذا التَّكـرار توكيـد وإلحسـاح علـى ضــرورة تطبيـق

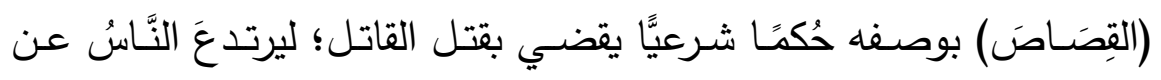
القتل؛ فَيَيَونَ حياةً آمنة مطمئنة. - ثانيًا: توظيف الوزن الشعري :

لجـأت النيابـة في هـذه المرافعـة إلى الاعتمــاد على بعض الجمـل الموزونة؛ لتحقيق تكوثر إيقاعي يعزّز من استمالة المخاطبين والتَّأثير فيهم. ومن ذلك قولها : - فطَغَوا وبَغَـوا.. واشـتدوا فـي اللَّدد. (على وزن المتدارك: فـاعلن فـاعلن فاعلن فاعلن). - فـدبَّروا .. وفكَّروا.. وقتلـوا.. وانتشـوا. (مخبـون الرجـز : مـتفعلن مـتفعلن متفعلن) تُخفِي الأذَي، وتُبِِّلْ الأوضَاعَا بِسمَتَ خَلائقُ كالسَّراب خَـوَادِ

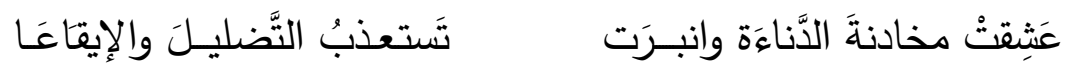
البيتان من الكامل (متفاعلن متفاعلن متفاعلن).

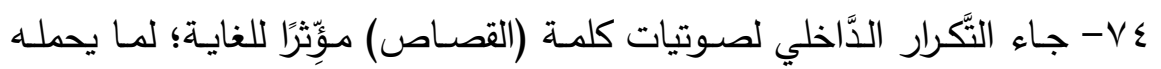
صوت (القاف) من قوةٍ وتمكُّن، أَتَتَاه من جهة كونهاته من الأصوات المجهورةِ الثَّدديدة

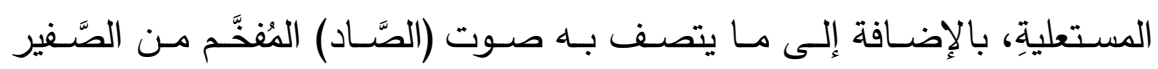
والاستعلاء. (راجـع: الجريسي، محمد مكي نصـر : نهايـة القول المفيد في علم

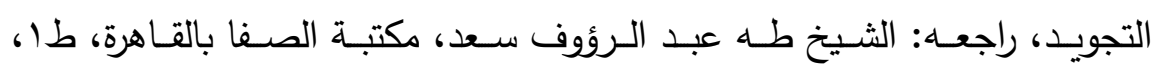

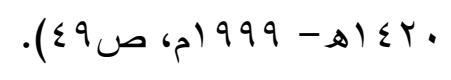




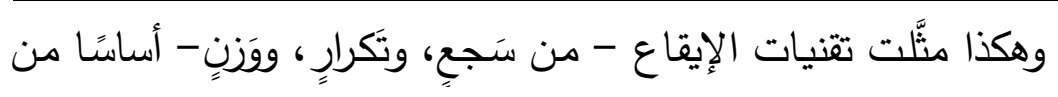

أسس استمالة المخاطبين والتأثير فيهم، ومن ثَم إقناعهم بموضوع ونحراتِ الخطاب، ودفعهم نحو اتخاذ الحكم المناسب.

*** 
ا - التفـتَّ البلاغيـون العـرب قـديمًا وحـديثًا إلـى توظيـف بعض التقَّنيـات البلاغيَّة في صناعة الخطاب الجاد، ولكنه التفاتُ يحتاج إلى مزيد من الجهد لتوسيعه.

r- تُعدُّ البلاغة بما تمتلكه من قدرة كبيرةٍ على التَّأثير والاستمالة، والإثبات والاستدلال عبر طاقاتها التَّكيبيَّة، والبيانيَّة، والإيقاعيَّة، إحدى تقنيات الحِجَاج • الناجح ب- أكََّّ البحث على أنَّ غلبة النزعة الجماليَّة على البلاغة العربيَّة لا ينفي عنها الوظيفة الحِجَاجيَّة. ع - أظهر البحث نجاحَ البلاغة العربيَّة في تجاوز إنتاج الخطاب الخَطابي (بفتح الخاء) الاحتفالي إلى إنتاج خطابات جادَّة ذات استراتيجيات ناجحة في تحقيق أهدافها. هـ كشف البحث عن الدَّور الذي تضطلعُ بـه البلاغـة في إنتاج خطـاب

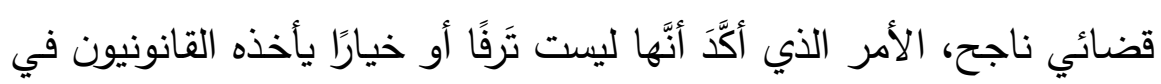
خطاباتهم أو يُهملونـه؛ وإنَّما هي أساس متين من أسس صناعة خطاباتهم، وآلية فاعلة من آلياته الحِجَاجيَّة.

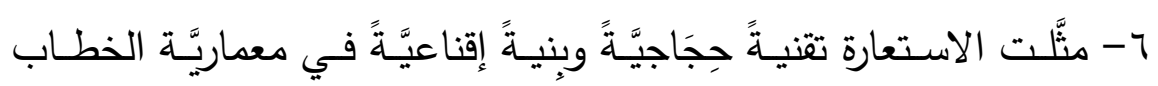
القضائي تبلورتُ بموجبها بعضُ الأدلة التي اقتضاها سياق الخطاب. V- أقامت الاستعارة في الخطاب القضائي علاقة تفاعلية مع المخاطَيين من

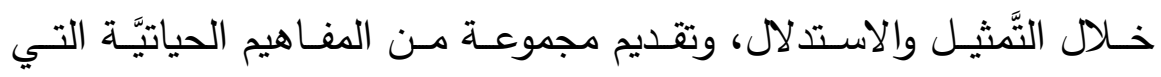
صاحبتُ عملية إدراكها وتأويلها. 
1- اسـتثمرَ الخطـاب القضــائي المعنـى المفـاهيمي للاسـتعارة في تعزيـز الحِجَاج، ومن ثَمَ تحقيق فعل الإقناع.

9- نجحت البلاغة عن طريق اشتغال آلياتها التَّكيبيَّة، والبيانيَّة، والإيقاعيَّة

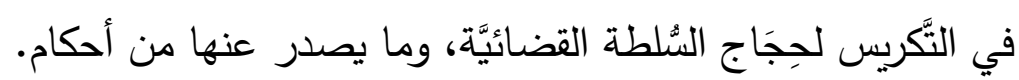
• 1- مثَّلَ أسلوب السُؤال تقنيةً حِجَاجيَّةً مهمة في الخطاب القضـائي كرَّست بثكل واضح لإدانة المتهم في سياق الاتهام، وفق الاستراتيجيات والأهداف التي خطط لها الخطاب.

1 - شكَّلَ الإيقاع في الخطاب القضائي وسيلةً مكرَّسةً بقوة من أجل تحقيق الاستمالة والتأثير على المخاطَبين على نحو يخدم أهداف الخطاب . r ا - يُعدُّ البحث أحـد روافد التَّأسيس النَّظري والتَّطبيقي لتحليـل الخطـاب القضائي من منظور الحِجَاج البلاغي. 


\section{توظيف تقنيات الحِجَاج البلاغي في الخطاب القضائي مقاربة في تحليل الخطاب الجاد}

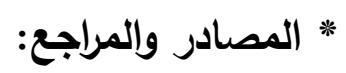

1- أرسطوطاليس: الخطابة، الترجمة العربية القديمة، حقَّقه وعلَّق عليه: عبد الـرَّحمن بـدوي، وكالـة المطبوعـات بالكويـــ، دار القــم، بيـروت - لبنـان، . ) $9 \vee 9$

ץ- الاسـتراباذي (محمـــــن الحسـن الرَّضــي) شـرح كافيـة ابـن الحاجـب، المكتبة العصرية، بيروت، طا، 99 (1) أهـ - 991 ام. r- أوكان، عمر: اللغة والخطاب، أفريقيا الشرق، المغرب، ( . ب م. ع - أوستن، جون: نظريـة أفعال الكلام، ترجمة: عبد القادر قينيني، إفريقيا

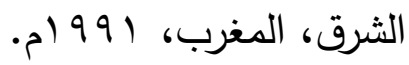

ه- البخاري (محمد بن إسماعيل): صـحيح البخـاري، تحقيق: جماعـة من

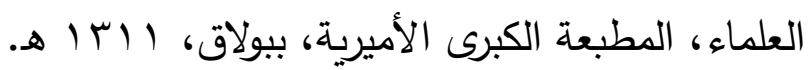
7- بلبع، عيد:

- أسلوبيَّة السُؤال، دار الوفاء للطباعة والنشر والتوزيع، ط ا، 999 ام. - مقدمة في نظرية البلاغة النبوية، السياق وتوجيه دلالة النص، بلنسيه

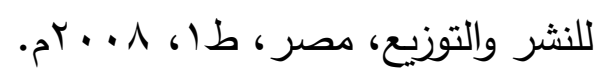
V- البهلـول، عبـد الله: الوصـايا الأدبيـة إلـى القـرن الرابـع هجريـا، مقارنــة

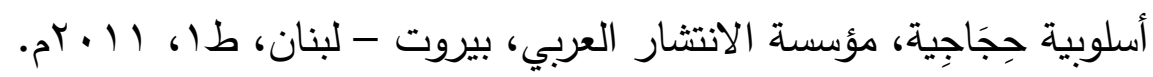
1- بليت، هنريش: البلاغة والأسلوبية، ترجمة وتقديم: محمد العمري، إفريقيا الثرق، المغرب، 999 (م. - (م. 9- الجرجاني (عبد القاهر بن عبد الرَّحمن) : 
- أسـرار البلاغـة، قرأه وعلَّق عليـه: محمـود شـاكر ، مطبعـة المـدني

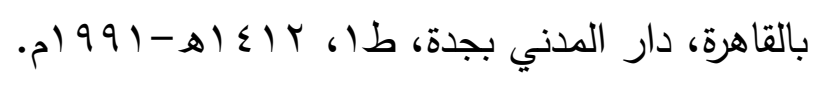

- دلائل الإعجاز ، تحقيق: محمود شاكر ، مطبعة المدني بالقاهرة -

$$
\text { دار المدني بجدة، طب، ساع إهـ - } 999 \text { ام. }
$$

• 1 - الجاحظ (أبو عثمان عمرو بن بحر): البيان والتبيين، تحقيق: عبد

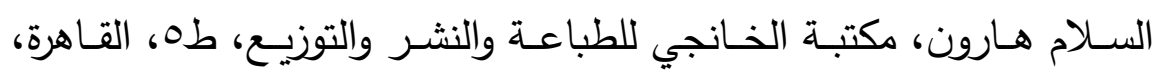

$$
\text { . } 9190-8 \mid \leq .0
$$

1 - ابن جني (أبو الفتح عثمان): الخصائص، تحقيق: محمد علي النجار، دار الكتب المصرية- المكتبة العلمية، القاهرة، د.ت.

r ا - الجريسي، محمد مكي نصـر : نهايـة القول المفيد في علم التجويد،

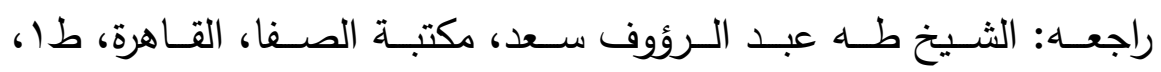

$$
\text { . ) } 999-81 \leqslant r \text {. }
$$

r ا - الحباشـة، صـابر : التداوليّة والحجاج، مداخل ونصوص، دار صفحات

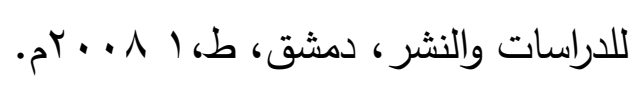

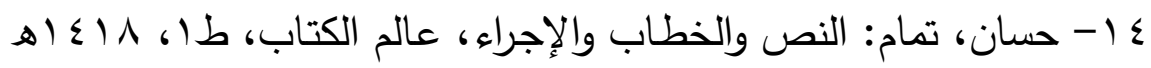

$$
\text { . } 1991-
$$

1 - الخفاجي (عبد الله بـن محمد بن سنان): سرُّ الفصـاحة، دار الكتب

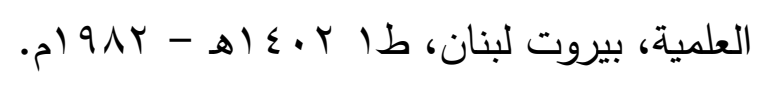

7 ا - ابن دريد (أبو بكر محمد بن الحسن): كتاب الملاحن، تحقيق: عبد الإله نبهان، منشورات وزارة الثقافة، دمشق، سورية، ب99 ام. 


\section{توظيف تقنيات الحِجَاج البلاغي في الخطاب القضائي مقاربة في تحليل الخطاب الجاد}

$$
\text { : l V }
$$

- الخطـاب والسـلطة، ترجمـة: غيـداء العلـي، مراجعـة: عمـاد عبـــ

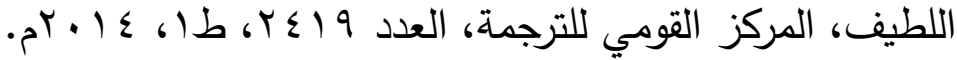
- النَّص والبِّياق، استقصـاء البحث في الخطاب الدلالِي التداولي، ترجمة: عبد القادر قنيني، إفريقيا الشرق، بيروت، . . . . 1 ا - ريكو، بول: الاستعارة الحيَّة، ترجمـة: محمد الولي، مراجعـة وتقديم، جورج زيناتي، دار الكتاب الجديد المتحدة، بيروت- لبنان، طا، 7 أ بام. 9 1 - السَّكاكي (أبو يعقوب يوسف بـن أبي بكر): مِفتاح العلوم، ضـبطه وكتب هوامشـهـ وعلَّق عليـه: نعـيم زرزور ، دار الكتب العلميـة، بيـروت -

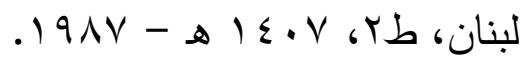

• r - سلوان، توماس أ: موسوعة البلاغة، ترجمة نخبة، إثراف وتقديم: عماد عبد اللطيف، مراجعة: عماد عبد اللطيف، مصطفى لبيب، المركز القومي

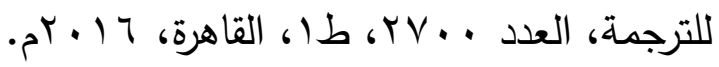
(Y-سيمينو، إيلينـا: الاستعارة في الخطـاب، ترجمـة: عمـاد عبد اللطيف،

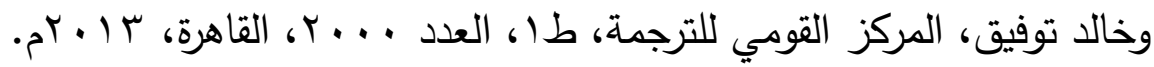
r Y - ابن سينا (أبو علي الحسين بن عبد الله): التعليقات، حقَّقهـه وقدَّم لـه: عبد الرَّحمن بدوي، الهيئة المصرية العامة للكتاب، القاهرة، سلو ام. rr- الثـهري، ظـافر : اسـتراتيجيات الخطـاب، مقاربـة لغويـة، دار الكتـاب الجديد المتحدة، ليبيا، طا، ع . . بم. 
ع Y- صولة، عبد الله: الحِجَاج أطره ومنطلقاته من خلال مصنف الحِجَاج، دار الفارابي، بيروت- لبنـان - منشورات كلية الآداب بمنوبـة، تونس، طب، $\cdot 5 r \cdot v$

هץ - عبد الرَّحمن، طه: اللسان والميزان أو التكوثر العقلي، المركز الثقافي العربي، الدار البيضاء، المغرب، طا، 991 ام.

جr - عريبي، زكي: لغة الأحكام والمرافعات، الكتاب الذهبي للمحاكم الأهلية

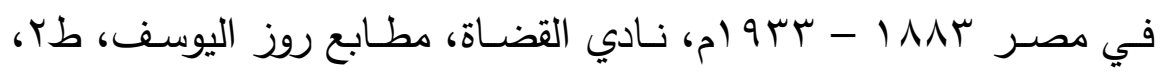
. $) 99$.

VV وتطبيقاتها، مركز الملك عبد الله بن عبد العزيز الدولي لخدمة اللغة العربية،

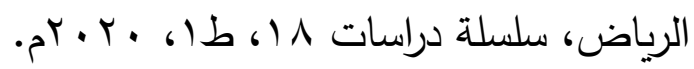
^ץ - فيركلف، نورمان: اللغة والسلطة، ترجمة: محمد عناني، المركز القومي

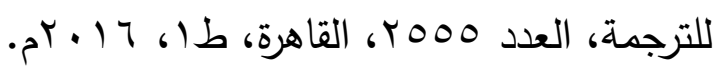
qr - القرطاجني (حازم بن محمد بن حسن): منهاج البلغاء وسراج الأدباء، تقديم وتحقيق: محمد الحبيب بن الخواجة، دار الغرب الإسـلامي، بيروت-

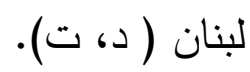

• ب- القزوينـي (محمـــــن عبـد الـرَّحمن): الإيضـــاح في علـوم البلاغـة،

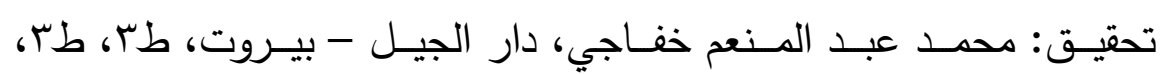
. 
اب- القيسي، مَكي بـن أبسي طالب: الرِّعايـة لتجويـد القراءة وتحقيق لفظ

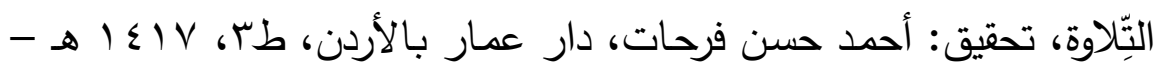
. $) 997$

بـ- المبخـوت، شكري: نظريـة الحِجَـاج فـي اللغـة، ضـمن أهـ نظريـات

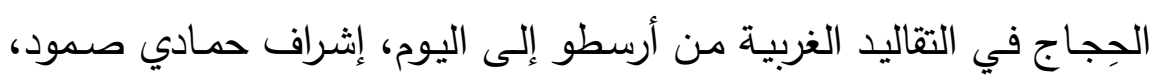
كلية الآداب، منونة، تونس، د.ت.

سب- المري، بهاء: هكذا ترافع العظمـاء - أدب المرافاعـات دفاعًا واتهامًا،

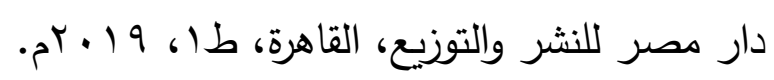
ع - ميلز، سـارة: الخطاب، ترجمـة: عبد الوهـاب علوب، المركز القومي

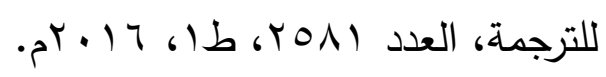
هr- النَّوي (أبو زكريا محيي الدين يحيى): شرح صحيح مسلم، دار إحياء

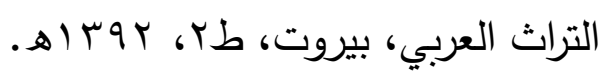

جب- الوالي، محمد: من بلاغـة الحِجَاج إلى بلاغة المحسنات، مجلة فكر

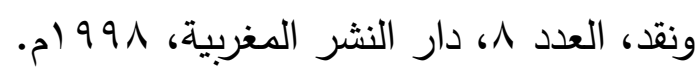
- المراجع الأجنبيَّة: - -

1. Bitzer, Lloyd the rhetorical situation. Philosophy and Rhetoric, 1968.

2. George A. Kennedy, Classical Rhetoric \& its Christian and Secular Tradition from Ancient to Modern Times, Chapel Hill: The University of North Carolina Press, 1999.

3. Laurent Pernot, Rhetoric in Antiquity, Washington, D.C: The Catholic University of America Press, 2005. 
4. Metaphor Analysis Critical to Approaches Approaches Jonathan Charteris London, 2004.

5. The New Rhetoric: A Treatise on Argumentation, Chaim Perelman, Tyteca. France, 1969.

6. van Dijk.T (ed) discourse studies. sage benchmark series. new Delhi; sage. 2007. 
توظيف تقنيات الحِجَاج البلاغي في الخطاب القضائي مقاربة في تحليل الخطاب الجاد 